\title{
Organic versus Conventional Cropping Sustainability: A Comparative System Analysis
}

\author{
Tiffany L. Fess ${ }^{(10)}$ and Vagner A. Benedito * \\ Division of Plant \& Soil Sciences, West Virginia University, P.O. Box 6108, Morgantown, WV 26506, USA; \\ tfess@mix.wvu.edu \\ * Correspondence: vagner.benedito@mail.wvu.edu
}

Received: 11 December 2017; Accepted: 16 January 2018; Published: 21 January 2018

\begin{abstract}
We are at a pivotal time in human history, as the agricultural sector undergoes consolidation coupled with increasing energy costs in the context of declining resource availability. Although organic systems are often thought of as more sustainable than conventional operations, the lack of concise and widely accepted means to measure sustainability makes coming to an agreement on this issue quite challenging. However, an accurate assessment of sustainability can be reached by dissecting the scientific underpinnings of opposing production practices and crop output between cropping systems. The purpose of this review is to provide an in-depth and comprehensive evaluation of modern global production practices and economics of organic cropping systems, as well as assess the sustainability of organic production practices through the clarification of information and analysis of recent research. Additionally, this review addresses areas where improvements can be made to help meet the needs of future organic producers, including organic-focused breeding programs and necessity of coming to a unified global stance on plant breeding technologies. By identifying management strategies that utilize practices with long-term environmental and resource efficiencies, a concerted global effort could guide the adoption of organic agriculture as a sustainable food production system.
\end{abstract}

Keywords: agricultural ecology; energy use efficiency; natural resources; organic breeding; pesticides; soil conservation; sustainable development

\section{Introduction}

\subsection{The Definition and State of Global Organic Production}

Organic crop production is practiced throughout the world, but the official definition and requirements vary country to country (Figure 1). In the United States, the definition of "organic" provided through the government regulated U.S. Department of Agriculture (USDA) National Organic Program (NOP) is not simple, but a rather lengthy and detailed description of all aspects associated with the production, handling, processing, and labeling of organic products, which are strictly enforced. In short, the NOP defines organic agriculture as "an ecological production management system that promotes and enhances biodiversity, biological cycles and soil biological activity. It is based on minimal use of off-farm inputs and on management practices that restore, maintain and enhance ecological harmony". It should be noted that the standards set by each individual country reflect the needs and resources of the local agricultural environment and consumer. Therefore, some variation does exist. Internationally, organic agriculture is regulated and enforced by numerous certifying agencies based, in large part, on standards set by the International Foundation for Organic Agriculture Movements (IFOAM). Generally speaking, standards set in all countries largely prohibit synthetic fertilizers and pesticides, and instead put heavy reliance on biodiversity, natural pathogen and pest controls, as well as crop rotations to maintain soil fertility, enhance system sustainability, and reduce environmental 
impact. Additionally, the use of material legally defined as a genetically modified organism (GMO) is strictly prohibited.

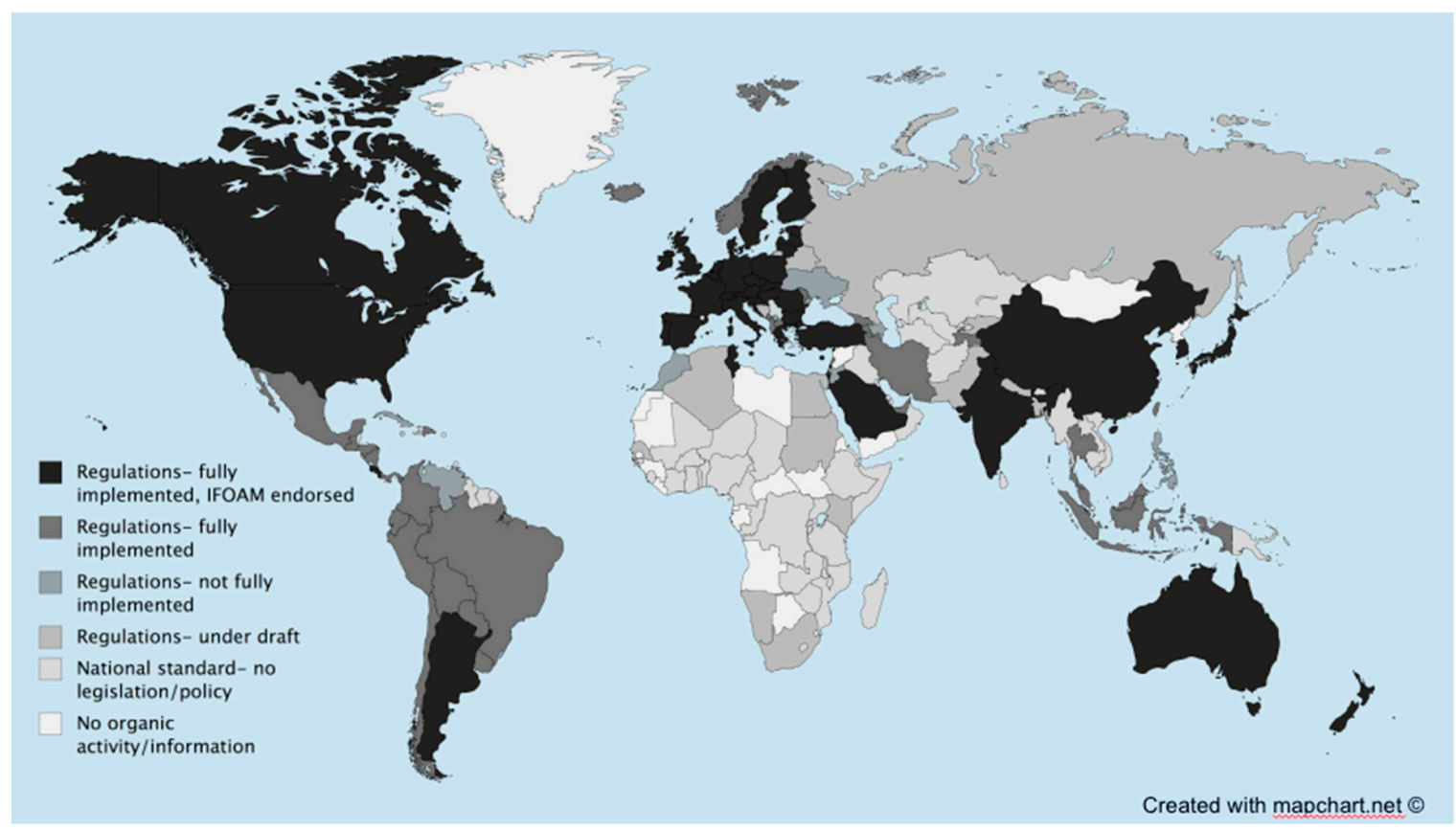

Figure 1. Regulation and implementation of organic practices by country. According to the most recent data from the Research Institute of Organic Agriculture (FiBL), organic agriculture is being practiced to some degree in almost all countries [1]. Map created using mapchart.net.

According to the most recent Research Institute of Organic Agriculture (FiBL) data (2015), there are 179 diverse organic producing countries in the world combining 50.9 million hectares of farmland dedicated to organic production, an area roughly the total size of Spain (Figure 2) [1]. In 2015, the largest number of organic producers worldwide was recorded, totaling 2.4 million, of which $89 \%$ are from developing countries and emerging markets (Figure 3). The most recent statistics also show that global sales of organic food and drinks are estimated to have reached 81.6 billion USD (Figures 4 and 5) [1]. Presently, organic agriculture and related businesses are growing within the U.S. market, serving as a strong stimulus for the USDA's goals for rural development and promotion of agricultural sustainability. Over the last 30 years, U.S. organic production has grown at a steady pace, starting from virtually nothing and growing to currently include over 14,800 registered farms, managing approximately 2.0 million hectares ( 4.9 million acres; $0.6 \%$ total land share) of farmland, with certifiable organic operations found in every state [1]. Even though the amount of land dedicated to the production of organic goods is low in comparison to its conventional counterpart, consumer demand is high. Overall, the U.S. organic market reached 39.7 billion USD in retail sales in 2015 (representing $47 \%$ of the global organic market), accounting for nearly $5 \%$ of all food sales in the U.S. [2]. According to surveys collected by the USDA, even though the retail price of organic products continues to be higher than their conventional counterparts, more organic producers are needed to meet the demand of the U.S. market, especially for fresh produce and dairy. 


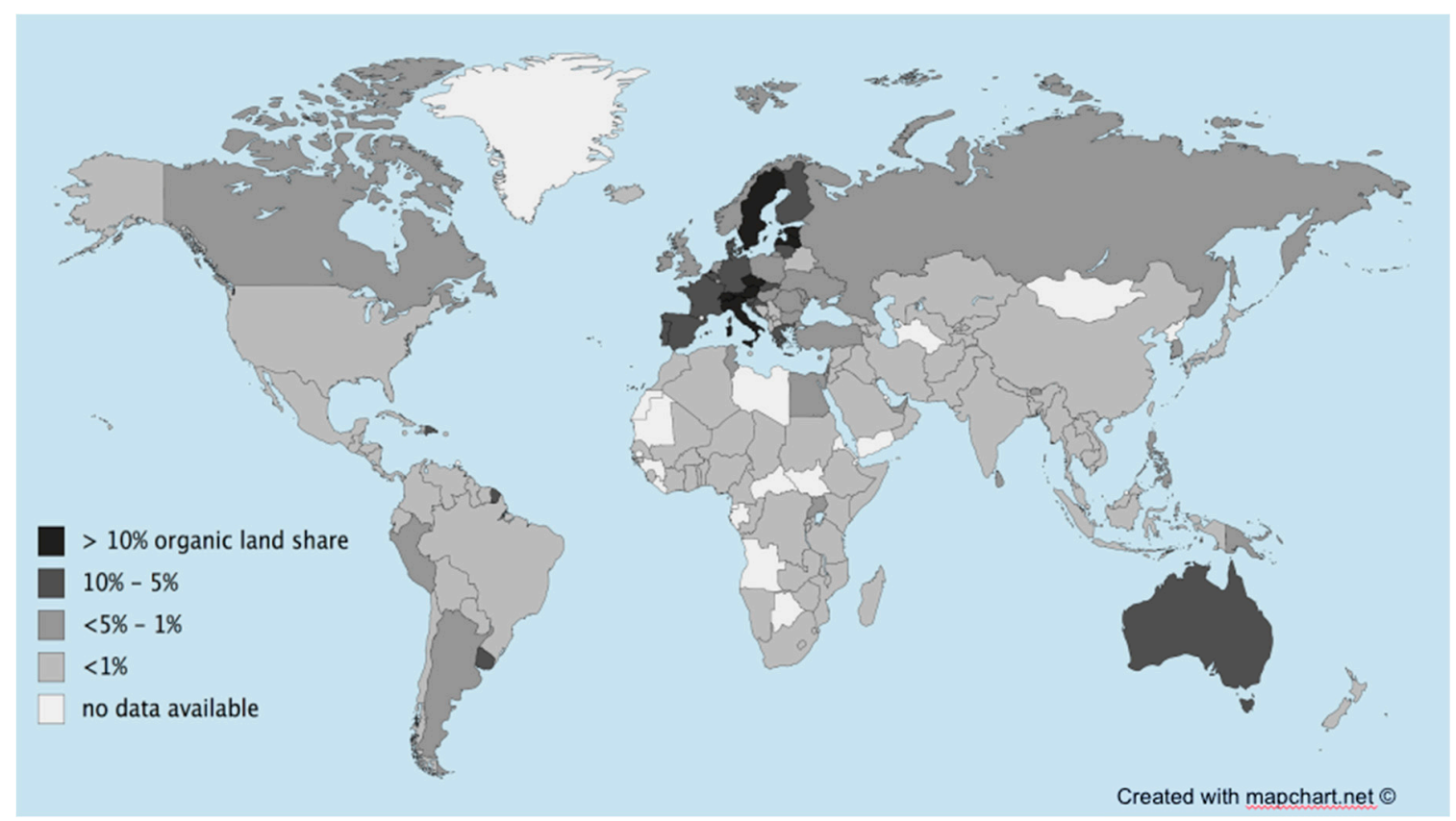

Figure 2. Proportion of organic land share, per country, as of 2015 . Currently, $1.1 \%$ of the global agricultural area is dedicated to organic crop production. Data retrieved from Research Institute of Organic Agriculture (FiBL) and International Federation of Organic Agriculture Movements (IFOAM)-Organic International World of Organic Agriculture Yearbook 2017 [1]. Map created using mapchart.net.

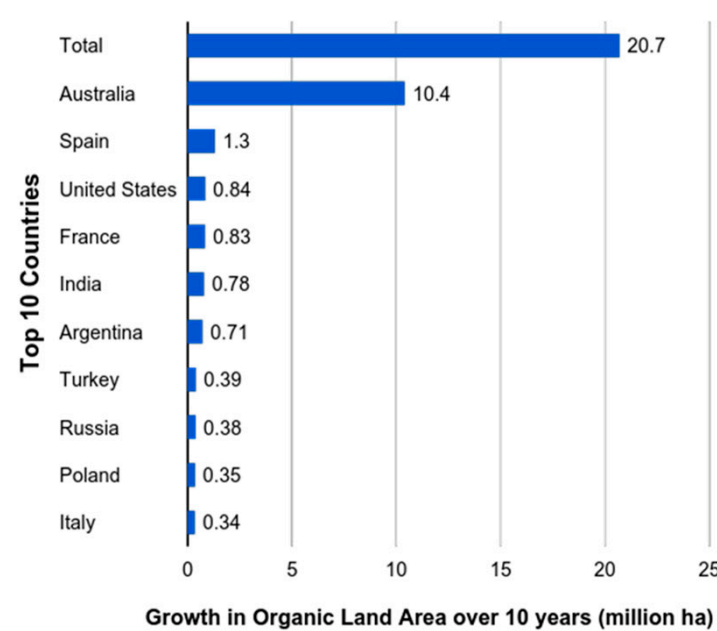

(a)

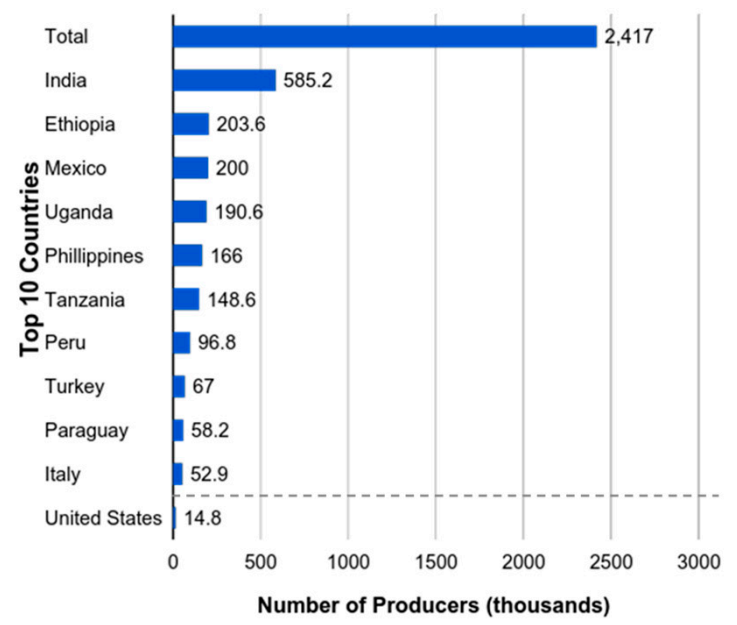

(b)

Figure 3. Global growth in organic production. In response to increasing global consumer demand, the land area and number of producers dedicated to the cultivation of organic goods has steadily increased over the last several decades. (a) Top ten countries with greatest increase in land area dedicated to organic production over the last 10 years; and (b) number of farmers dedicated to organic production in the top ten countries plus the United States (15th), as of 2015. Data compiled from Research Institute of Organic Agriculture (FiBL) and International Federation of Organic Agriculture Movements (IFOAM)-Organic International World of Organic Agriculture Yearbook 2017 [1]. 


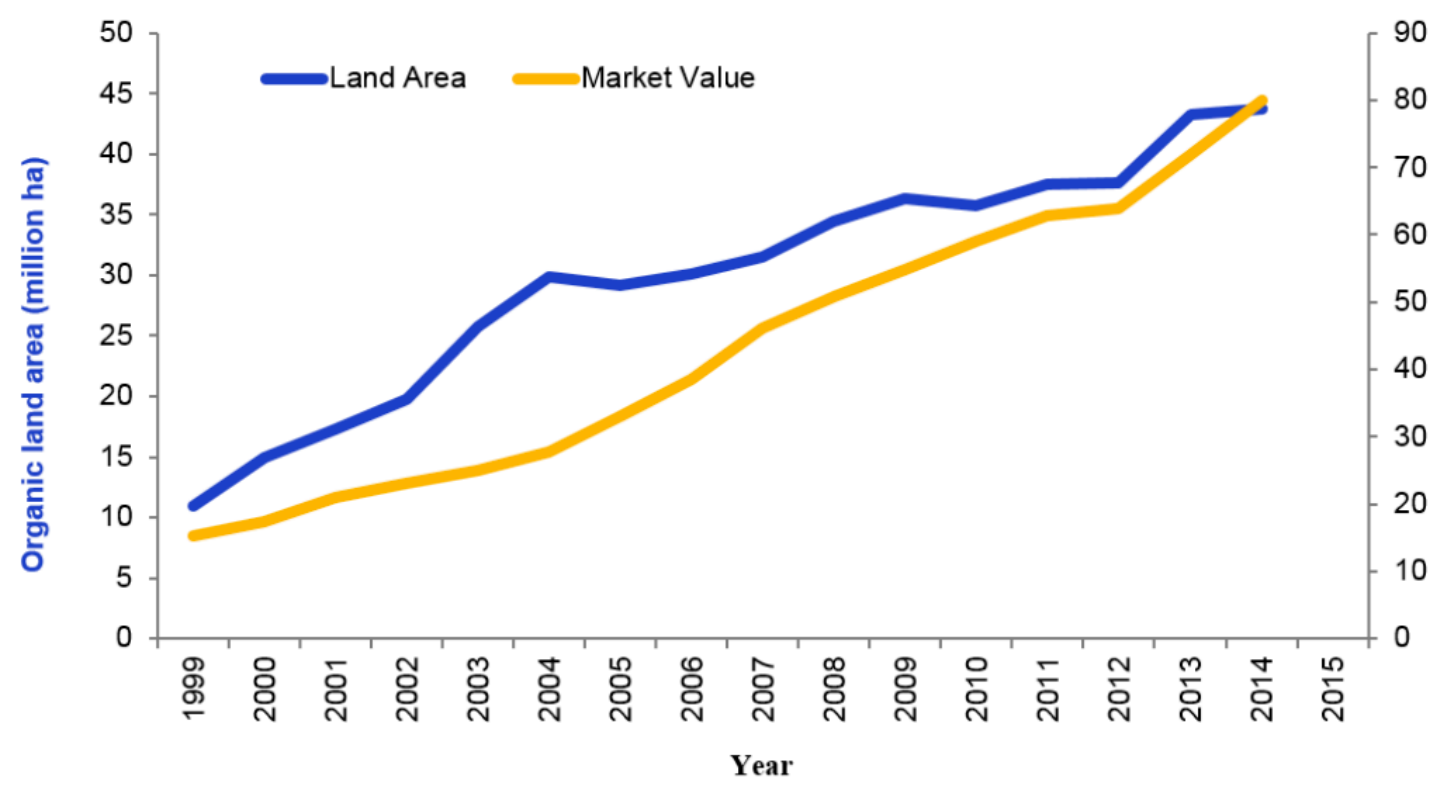

Figure 4. Trends in global area and market value of organic production. Data compiled from Research Institute of Organic Agriculture (FiBL) and International Federation of Organic Agriculture Movements (IFOAM)-Organic International World of Organic Agriculture Yearbook 2001-2017 [1].

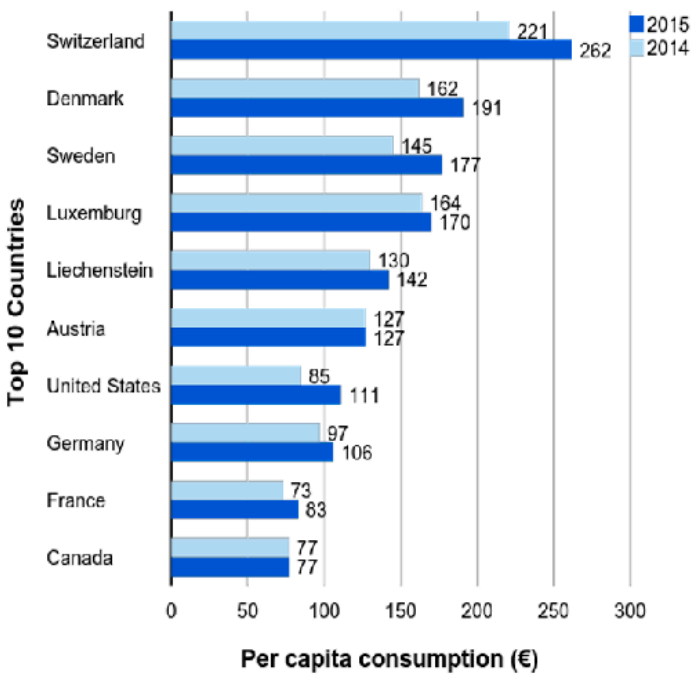

(a)

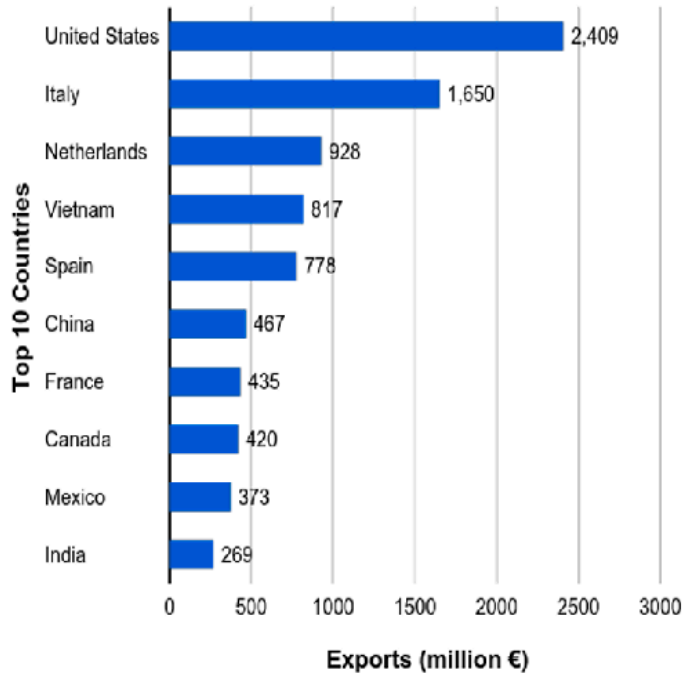

(b)

Figure 5. Per capita consumption (a); and exportation (b) of organic products. Top ten countries are shown. Data source: Research Institute of Organic Agriculture (FiBL) and International Federation of Organic Agriculture Movements IFOAM-Organic International World of Organic Agriculture Yearbook 2017 [1].

\subsection{The State of Sustainability in Global Agriculture}

Sustainability is a complex concept comprised of many intertwining factors and lacking widely accepted assessment methods, which poses challenges in assessing the level of sustainability of agricultural systems. Generally, agricultural sustainability refers to crop (or livestock) production using farming techniques that can provide human food and raw materials needs over the long-term, as well as reducing the environmental impact while maintaining the economic viability and improving the quality of life for farmers, and society as a whole. 
In the U.S., modern agriculture is largely dominated by conventional or industrial production systems, with approximately 2.1 million farms covering roughly 373 million hectares [3]. Conventionally managed systems are characterized as high-input operations with heavy dependence on off-farm resources and large capital investment. These production systems often consist of large-scale monocultures relying on heavy machinery, use of irrigation, high-yielding hybrid varieties, synthetic fertilizers, and frequent pesticide applications. Although conventional agriculture has led to the development of convenient farming practices through mechanical and technological innovations that have resulted in the adequate production of an inexpensive food supply. This type of system has focused mainly on maximizing productivity and profitability, subsequently creating a fundamentally unsustainable situation for the rapidly growing global population. Organic systems, on the other hand, rely on the management of on-farm resources, embracing a whole-system approach to food production, which consequently results in an approach that is perceived as more sustainable in comparison to modern conventional systems.

Although most would agree that sustainable and organic are closely related terms, as per their own definitions, some discrepancy remains over the extent of their association. Issues concerning environmental impact, production cost, reliance on nonrenewable resources and inorganic chemicals, and soil degradation are important parameters when evaluating agricultural sustainability at a whole systems level. Reganold et al. [4] assessed the sustainability of three apple production systems (organic, conventional, and mixed) by measuring soil quality parameters, horticultural performance and energy cost. The combined results showed that organic and mixed systems had better sustainability scores than the conventional counterpart, but that production parameters of each farm system were economically inviable and, therefore, unsustainable. A separate study comparing sustainability of (organic, conventional, and mixed) farming systems using 24 economic and environmental indicators revealed that, even though organic farming systems generally complied with threshold standards, organic production did not equate to complete sustainability, especially from an environmental standpoint [5]. Overall, without a clear definition and a consensus of standards in which to measure it, determining the sustainability of a particular agriculture system or how to improve it will remain elusive.

Given the increasing demand for organic products, questions concerning the ability of organic systems to sustainably meet the current and future global agricultural demands have been raised numerous times. This is a widely debated issue, to which opponents often cite low crop output as the primary constraint limiting the confidence of agricultural stakeholders in the ability of organically managed systems to meet the population's needs. Although yield is often the main aspect of crop output discussed when comparing whole-system conventional and organic management, there are several other differences that should be considered when evaluating the final crop product, including the sustainability of the agricultural practices used to produce it (including long-term viability of the system and environmental impact), as well as economic performance and nutritional content of the product.

The remainder of this review provides a comparative dissection of system production inputs and crop outputs to evaluate sustainability between organic and conventional management strategies. It should be clearly noted that it is not the purpose of the authors to review organic methodologies alone but to compile the scientific literature as evidentiary support to better understand system cropping practices (excluding livestock) while framing sustainability. The literature selected to complete the objective at hand consisted of recent meta-analyses and refereed original research presenting data collected in-field with direct experimental comparison between organic and conventional production practices or crop output, many of which were long-term studies.

\section{Sustainability and Organic Production Parameters}

Due to the increasing concerns over the impact of agriculture on the environment, numerous studies have focused on determining the influence of production practices on various aspects 
including soil characteristics, consumption of nonrenewable resources, and environmental pollution. Over the years, data from an extensive body of research has demonstrated differences between system production methodologies, the most notable being soil fertility, pest management, and energy consumption. By comparing these parameters within each system individually, the long-term feasibility of each strategy can be reached, indicating areas for improvement, while collectively assessing the sustainability of the whole-system management.

\subsection{Soil Fertility Management}

In terms of soil management, the main opposing production parameters between conventional and organic systems involve the management of soil fertility. Nutrients are supplied in conventional systems, generally monocultures, primarily by means of synthetic inorganic fertilizers, while soil fertility in organic systems is managed largely with cover crops, green and animal manures, and compost amendments, in addition to crop rotations. Since the soil environment is complex and difficult to evaluate using just one indicator, several physical, chemical, and biological properties have been examined to compare the impact of organic production on the soil. Numerous investigations have shown that soil organic matter was improved in fields under organic management compared conventional management (Table 1 and references within). Increased soil organic matter correlated with improved soil structure and aggregate stability, water infiltration and holding capacity, as well as diversity and activity of soil organisms, which often are characteristic of organically managed soils. Studies have found that soil concentrations of $\mathrm{P}, \mathrm{K}, \mathrm{Ca}$, and $\mathrm{Mg}$ are significantly greater in organic fields. The pool of data available illustrates the importance of manure and compost applications in organic systems. The removal of P-input resulted in soils with decreased soluble $\mathrm{P}$ and negative $\mathrm{P}$ balance, which invariably leads to increased $\mathrm{P}$ mining and depletion, limiting the long-term productivity and sustainability of the system. Organic fertility management also provides a viable environment that supports a diverse population of beneficial soil macrofauna, including arthropods and earthworms compared to those of conventionally managed soils (Table 1). Microbial biomass, diversity, and activity have also been consistently greater in fields under crop rotations and organic soil amendments in comparison to soils under culture repetition or receiving strictly mineral fertilizers (Table 1). Data generated by Henneron et al. [6] suggest that improvements in soil microbial diversity and biomass, in turn help to support the larger populations of macroorganisms that were also found enriched in fields under organic management. Soil population increases, likely due to higher levels of organic matter and crop residues present in the soil, additionally benefit from larger root systems resulting from increased nutrient foraging common of organically produced crops. However, it is important to point out that these studies did not find significant differences in soil quality until after several years under organic management.

Table 1. Comparative Studies on Soil Fertility Management (in chronological order).

\begin{tabular}{|c|c|}
\hline Citation & Major Conclusions \\
\hline \multirow{2}{*}{ Drinkwater et al., 1995 [7] } & $\begin{array}{l}\text { In commercial tomato fields, } \mathrm{N} \text { mineralization potential was found to be } \\
\text { three times greater and inorganic pools were } 25 \% \text { greater in organic than } \\
\text { conventional fields after three seasons. }\end{array}$ \\
\hline & $\begin{array}{l}\text { Organically managed soils have a greater portion of inorganic } \mathrm{N} \text { present } \\
\text { as } \mathrm{NH}_{4}{ }^{+} \text {compared to } \mathrm{NO}_{3}{ }^{-} \text {. }\end{array}$ \\
\hline Clark et al., 1998 [8] & $\begin{array}{l}\text { Organic soils receiving manure application and cover crop incorporation } \\
\text { were found to have higher soil organic } C \text {, soluble } P \text {, exchangeable } K \text {, and } \\
\mathrm{pH} \text { compared to soil from conventional systems. }\end{array}$ \\
\hline
\end{tabular}


Table 1. Cont.

\begin{tabular}{|c|c|}
\hline Citation & Major Conclusions \\
\hline \multirow{3}{*}{ Bulluck et al., 2002 [9] } & $\begin{array}{l}\text { Concentrations of soil } \mathrm{Ca}, \mathrm{K}, \mathrm{Mg}, \mathrm{Mn} \text { were higher in soils under organic } \\
\text { fertility management after two years. }\end{array}$ \\
\hline & $\begin{array}{l}\text { Mean soil organic matter, total C, and CEC were higher whereas bulk } \\
\text { density was reduced in plots with organic fertility amendments. }\end{array}$ \\
\hline & $\begin{array}{l}\text { Propagule densities of Trichoderma spp. were greater in soils with organic } \\
\text { fertility amendments than synthetic fertilizer. }\end{array}$ \\
\hline \multirow{2}{*}{ Mader et al., 2002 [10] } & $\begin{array}{l}\text { The 21-year study revealed increased aggregate stability, as well as } \\
\text { earthworm and microbial biomass in soils under organic management } \\
\text { compared to conventionally managed soils. }\end{array}$ \\
\hline & $\begin{array}{l}\text { Dehydrogenase, protease, and phosphatase activities were greater in } \\
\text { fields managed organically compared to conventional fields, indicating } \\
\text { higher microbial activity. }\end{array}$ \\
\hline \multirow{3}{*}{ Poudel et al., 2002 [11] } & $\begin{array}{l}\text { After five seasons, organic systems were found to have } 112 \% \text { greater } \\
\text { potentially mineralizable } \mathrm{N} \text { than conventional systems. }\end{array}$ \\
\hline & $\begin{array}{l}\text { Twice the amount of soil mineral } \mathrm{N} \text { was found to be present in the } \\
\text { conventional system }\left(44.10 \mathrm{mg} \mathrm{kg}^{-1}\right) \text { compared to the organic counterpart } \\
\left(20.19 \mathrm{mg} \mathrm{kg}^{-1}\right) \text {. }\end{array}$ \\
\hline & $\begin{array}{l}\mathrm{N} \text { mineralization rates in fields under conventional management were } \\
\text { found to be } 100 \% \text { than those under organic management, increasing the } \\
\text { risk for } \mathrm{N} \text { leaching. }\end{array}$ \\
\hline Sileika and Guzys, 2003 [12] & $\begin{array}{l}\text { No differences in } \mathrm{N} \text { or } \mathrm{P} \text { leachate were found between field drainage from } \\
\text { organic cropping systems receiving manure compared to intensive } \\
\text { systems receiving mineral fertilization. }\end{array}$ \\
\hline \multirow[b]{2}{*}{ * Bengtsson et al., 2005 [13] } & $\begin{array}{l}\text { Meta-analysis revealed that organic practices increased species richness } \\
30 \% \text { than to conventional system practices. }\end{array}$ \\
\hline & $\begin{array}{l}\text { Fields under organic management were found to have } 50 \% \text { greater } \\
\text { abundance of organisms; birds, predatory insects, soil flora and fauna } \\
\text { responded positively to organic fields. }\end{array}$ \\
\hline Meng et al., 2005 [14] & $\begin{array}{l}\text { Organic soils fertilized with manures have greater soil C and } \mathrm{N} \text { content, } \\
\text { lower bulk density, and pore space than conventional soils supplied only } \\
\text { mineral fertilizers. }\end{array}$ \\
\hline \multirow[t]{2}{*}{ Pimentel et al., 2005 [15] } & $\begin{array}{l}\text { Soil C levels in animal and legume-based organic cropping systems were } \\
\text { significantly higher than conventional systems, 981, 574, } \\
293 \mathrm{~kg} \mathrm{ha}^{-1} \text {, respectively. }\end{array}$ \\
\hline & $\begin{array}{l}\text { Soil } \mathrm{N} \text { increased under organic management, while the conventional } \\
\text { system remained unchanged. }\end{array}$ \\
\hline \multirow[t]{2}{*}{ Kramer et al., 2006 [16] } & $\begin{array}{l}\text { Soils under organic management had higher organic matter content, } \\
\text { microbial biomass } \mathrm{C} \text { and } \mathrm{N} \text {, and denitrification potential resulting from } \\
\text { the use of organic fertility amendments and cover cropping than } \\
\text { mineral fertilizers. }\end{array}$ \\
\hline & $\begin{array}{l}\text { Nitrate leaching was found to be around } 5 \text { times greater in conventional } \\
\text { fields than organic, while } \mathrm{N}_{2} \text { emissions were greater in organic fields. }\end{array}$ \\
\hline \multirow{3}{*}{ Torstensson et al., 2006 [17] } & $\begin{array}{l}\text { Over a 6-year period, leaching loads of } \mathrm{N} \text { were found to be the smallest in } \\
\text { fields using integrated practices, particularly those utilizing cover crops } \\
25 \mathrm{~kg} \mathrm{~N} \mathrm{ha}^{-1} \text { year }^{-1} \text {. }\end{array}$ \\
\hline & P leaching were small in general in all systems, $<0.25 \mathrm{~kg} \mathrm{ha}^{-1}$ year $^{-1}$. \\
\hline & $\begin{array}{l}\text { Soils under organic management showed reduced } \mathrm{K} \text { leachate compared to } \\
\text { conventional systems, } 16 \text { and } 23 \mathrm{ha}^{-1} \text { year }^{-1} \text {, respectively. }\end{array}$ \\
\hline
\end{tabular}


Table 1. Cont.

\begin{tabular}{|c|c|}
\hline Citation & Major Conclusions \\
\hline \multirow{3}{*}{ Tu et al., 2006 [18] } & $\begin{array}{l}\text { Tomato fields produced using composted plant debris had higher soil } \\
\text { microbial respiration, carbon }\left(\mathrm{C}_{\text {mic }}\right) \text { and nitrogen }\left(\mathrm{N}_{\text {mic }}\right) \text { compared to } \\
\text { those where synthetic fertilizers were utilized. }\end{array}$ \\
\hline & $\begin{array}{l}\text { Microbial biomass and activity were higher in soil under cultivation of } \\
\text { organic tomatoes compared to conventional. }\end{array}$ \\
\hline & $\begin{array}{l}\text { Cotton gin trash and straw mulch improved microbial biomass, activity, } \\
\text { and potential } \mathrm{N} \text { availability compared to conventional fertility practices. }\end{array}$ \\
\hline \multirow{2}{*}{ van Diepeningen et al., 2006 [19] } & $\begin{array}{l}\text { Significantly lower levels of nitrate and total soluble } \mathrm{N} \text { were found in soils } \\
\text { under organic management compared to conventional. }\end{array}$ \\
\hline & $\begin{array}{l}\text { Organic soil showed greater species richness of soil bacteria and } \\
\text { nematodes compared to conventional soils. }\end{array}$ \\
\hline \multirow{2}{*}{ Yao et al., 2006 [20] } & $\begin{array}{l}\text { Soils under continuous cropping had reduced total } \mathrm{C} \text { and } \mathrm{N} \text { compared to } \\
\text { those utilizing rotational practices. }\end{array}$ \\
\hline & $\begin{array}{l}\text { Soil microbial diversity was significantly greater in rotational cucumber } \\
\text { crops compared to continuous cropping. }\end{array}$ \\
\hline \multirow{3}{*}{ Fließbach et al., 2007 [21] } & $\begin{array}{l}\text { Conventionally managed soils had } 25 \% \text { reduction in microbial biomass } \\
\text { compared to organic systems. }\end{array}$ \\
\hline & Dehydrogenase activity was $\sim 40 \%$ higher in organically managed soils. \\
\hline & $\begin{array}{l}\text { Annual applications of manure-compost resulted in } 12 \% \text { higher soil C } \\
\text { content than the conventional fertilization method. }\end{array}$ \\
\hline \multirow{4}{*}{ Liu et al., 2007 [22] } & $\begin{array}{l}\text { Soils from organic and sustainable farms had improved soil health as } \\
\text { indicated by several physical, chemical, and biological factors, as well as } \\
\text { reduced disease incidence. }\end{array}$ \\
\hline & $\mathrm{Ca}, \mathrm{Mg}, \mathrm{Mn}, \mathrm{P}, \mathrm{Zn}$, and $\mathrm{Cu}$ were greater in soils under organic production. \\
\hline & $\begin{array}{l}\text { Populations of fungi and thermophiles were significantly higher in soils } \\
\text { from organic than conventional fields. }\end{array}$ \\
\hline & $\begin{array}{l}\text { Soil bacterial functional diversity indices were higher in soils from } \\
\text { organic farms. }\end{array}$ \\
\hline \multirow{2}{*}{ Birkhofer et al., 2008 [23] } & $\begin{array}{l}\text { Systems receiving farmyard manure had a greater abundance of soil } \\
\text { microbes (fungi and bacteria), bacterivorous nematodes, earthworms, and } \\
\text { spiders than conventional systems. }\end{array}$ \\
\hline & $\begin{array}{l}\text { Bacterial and fungal phospholipid-derived fatty acid (PLFA) markers } \\
\text { increased roughly } 17 \% \text { in fields receiving organic forms of fertilization } \\
\text { compared to mineral fertilizer. }\end{array}$ \\
\hline \multirow{2}{*}{ Evanylo et al., 2008 [24] } & $\begin{array}{l}\text { Soil organic } \mathrm{C} \text {, total } \mathrm{N} \text {, and available } \mathrm{P} \text { increased } 60 \%, 68 \%, 225 \% \text {, } \\
\text { respectively, with the addition of compost in organic vegetable cropping } \\
\text { systems compared to the conventional counterpart. }\end{array}$ \\
\hline & $\begin{array}{l}\text { Compost additions contributed the lowest amounts of all combined forms } \\
\text { of } \mathrm{N} \text { to the runoff load. }\end{array}$ \\
\hline \multirow{3}{*}{ * Mondelaers et al., 2009 [25] } & $\begin{array}{l}\text { A meta-analysis concluded that soils in organic systems had higher } \\
\text { organic matter content. }\end{array}$ \\
\hline & $\begin{array}{l}\text { Organic fertility practices positively influenced natural biodiversity } \\
\text { organisms in the soil and landscape. }\end{array}$ \\
\hline & $\begin{array}{l}\text { Scores representing nitrate and phosphorus leaching and greenhouse gas } \\
\text { emissions from organic farms were better than conventional farms. }\end{array}$ \\
\hline
\end{tabular}


Table 1. Cont.

\begin{tabular}{|c|c|}
\hline Citation & Major Conclusions \\
\hline \multirow{2}{*}{ * Tuomisto et al., 2012 [26] } & $\begin{array}{l}\text { Soil organic matter content was } 7 \% \text { greater in organic than } \\
\text { conventional farms. }\end{array}$ \\
\hline & $\begin{array}{l}\text { Nitrogen leaching per unit of area was } 31 \% \text { lower from organic farming } \\
\text { compared to conventional farming. }\end{array}$ \\
\hline \multirow{3}{*}{ Hilton et al., 2013 [27] } & $\begin{array}{l}\text { Direct comparison of crop rotations to monocultures, revealed that oilseed } \\
\text { rape rotations had a significant effect on the microbial community } \\
\text { structure and abundance in the rhizosphere. }\end{array}$ \\
\hline & $\begin{array}{l}\text { Specifically, crop rotation affected fungal populations more so than the } \\
\text { bacterial community in the soil. }\end{array}$ \\
\hline & $\begin{array}{l}\text { Populations of fungal pathogens affecting cabbage and tomato were } \\
\text { reduced in fields where rotations were employed compared to } \\
\text { continuous monocultures. }\end{array}$ \\
\hline * McDaniel et al., 2014 [28] & $\begin{array}{l}\text { Adding at least one or more crops in rotation to a monoculture } \\
\text { significantly improved both microbial biomass C and N, } 21 \% \text { and } \\
26 \% \text {, respectively. }\end{array}$ \\
\hline \multirow[t]{2}{*}{ Hartmann et al., 2015 [29] } & $\begin{array}{l}\text { Organic fields were characterized by ribosomal pyrosequencing with } \\
\text { increased species richness, including distinct groups of soil microbes } \\
\text { associated with the breakdown of complex organic compounds. }\end{array}$ \\
\hline & $\begin{array}{l}\text { Firmicute bacteria (Bacillus and Thermobacillus) were found to be the only } \\
\text { phylum in which all operational taxonomic units responded exclusively to } \\
\text { systems receiving fertilization from farmyard manures. }\end{array}$ \\
\hline \multirow{2}{*}{ Henneron et al., 2015 [6] } & $\begin{array}{l}\text { Organic systems had a greater abundance of the three ecological groups of } \\
\text { the Lumbricidae family of earthworms (anecic, endogeic, and epigeic) } \\
\text { than conventional operations. }\end{array}$ \\
\hline & $\begin{array}{l}\text { Soil bacteria significantly increased under organic management } \\
\left(1.35 \times 10^{10} \text { gene copies } g^{-1} \text { soil }\right) \text { compared to the conventional system } \\
\left(1.04 \times 10^{10} \text { gene copies } g^{-1} \text { soil }\right)\end{array}$ \\
\hline \multirow{2}{*}{ van Bruggen et al., 2015 [30] } & $\begin{array}{l}\text { Increased microbial activity was found in soils associated with organic } \\
\text { fertilization methods compared to conventional practices. }\end{array}$ \\
\hline & $\begin{array}{l}\text { Disease severity of corky root in lettuce was significantly greater under } \\
\text { conventional compared to organic management, 59\% and 5\%, respectively. }\end{array}$ \\
\hline Agegnehu et al., 2016 [31] & $\begin{array}{l}\text { Compost and biochar significantly improved exchangeable } \mathrm{K}, \mathrm{Ca} \text {, and } \mathrm{Mg} \\
\text { in Nitisol soils of South Africa after one season of application compared to } \\
\text { mineral fertilizers at multiple application rates. }\end{array}$ \\
\hline${ }^{*}$ Venter et al., 2016 [32] & $\begin{array}{l}\text { Soil under higher diversity of crops in rotation had greater microbial } \\
\text { diversity }(+15 \%) \text { and richness }(+3 \%) \text { compared to monocultures. }\end{array}$ \\
\hline \multirow{2}{*}{ Maharjan et al., 2017 [33] } & $\begin{array}{l}\text { Microbial biomass and total organic } \mathrm{C} \text { and } \mathrm{N} \text { contents were significantly } \\
\text { higher in organic topsoil compared with conventional farming systems. }\end{array}$ \\
\hline & $\begin{array}{l}\text { Enzyme activity, except for xylanase and acid phosphatase, were also } \\
\text { higher in soil from organic systems. }\end{array}$ \\
\hline \multirow{2}{*}{ Tian et al., 2017 [34] } & $\begin{array}{l}\text { A } 35 \text {-year fertilization study revealed soil organic matter was higher after } \\
\text { long-term manure applications. }\end{array}$ \\
\hline & $\begin{array}{l}\text { The abundance of soil bacteria and fungi were greater after applications of } \\
\text { manure compared to mineral fertilizers. }\end{array}$ \\
\hline
\end{tabular}

* Indicates a meta-analysis study. 
The collective data indicate that differences in soil quality and microbial activity under organic and conventional fertility management corresponded to differences in $\mathrm{N}$ availability. Organically managed soils were consistently characterized by reduced pools of instantaneous mineral $\mathrm{N}$ in combination with increased microbial activities and potentially mineralizable $\mathrm{N}$ pools (which indicates $\mathrm{N}$ availability) compared to soils managed using synthetic fertilization. The combination of soil characteristics induced through soil management practices common in organic systems can result in a more tightly-coupled $\mathrm{N}$ cycle (i.e., less $\mathrm{N}$ losses by denitrification and leaching) than those observed in conventional systems. This more tightly-coupled $\mathrm{N}$ cycle is accomplished through increased plant-soil-microbe soil $\mathrm{N}$ interactions and turnover of inorganic $\mathrm{N}$ resulting from organic management practices that increase soil $\mathrm{C}$ availability and thereby microbial biomass $\mathrm{N}\left(\mathrm{N}_{\text {mic }}\right)$ demand and gross $\mathrm{N}$ transformation rates [35]. Indeed, Bowles et al. [35] found that the $\mathrm{N}_{\text {mic }}$ and mineralizable $\mathrm{N}$ potential were strongly related to the expression of the glutamine synthetase gene (GS1), an enzyme required for direct assimilation of $\mathrm{NH}_{4}{ }^{+}$in the root cells, providing evidence that organic systems foster a tightly-coupled plant-soil $\mathrm{N}$ cycle. The current research pool also indicates that the rate of $\mathrm{N}$ mineralization in conventional systems was significantly greater than in organic fields (Table 1 ). The high $\mathrm{N}$ supplying capacity of organically managed soils, due to the high organic matter content coupled with increased biological activity and a lower mineralization rate, allows for the accumulation of more assimilated $\mathrm{N}$ forms, reducing the potential of organic fields to undergo heavy $\mathrm{N}$ leaching.

In all agricultural systems, whether under conventional or organic management, one of the major concerns regarding fertilization is the potential for nutrient leaching and runoff, particularly of $\mathrm{N}$ and $\mathrm{P}$, both of which are serious contributors to water pollution [36]. Current data suggest that soils managed organically have a greater portion of inorganic $\mathrm{N}$ present as $\mathrm{NH}_{4}{ }^{+}$than $\mathrm{NO}_{3}{ }^{-}$compared to those managed conventionally (Table 1). Studies addressing environmental impacts of agriculture revealed that the majority of organic soils show a decrease in $\mathrm{NO}_{3}{ }^{-}$leachate, while enhanced $\mathrm{N}_{2}$ emissions were found in the same soils (Table 1). These data suggest that the differences in fertilization practices between organic and conventional systems shift the balance of gaseous and leaching $\mathrm{N}$ losses, resulting in more $\mathrm{N}$ lost as $\mathrm{N}_{2}$ in organic systems while a greater portion is lost as $\mathrm{NO}_{3}{ }^{-}$from conventional systems. It should also be understood that organic fertility amendments differ based on their chemical composition and therefore can be consumed or converted by soil organisms at different rates. Comparing organic manures, Gomez-Lopez and del Amor [37] recorded that poultry litter resulted in three times greater concentration of soil $\mathrm{NO}_{3}{ }^{-}$and higher potential for pollution compared to horse and sheep manures: 3,058, 956, and 877 ppm, respectively. Even though there is potential cause for environmental impact due to leaching and runoff of agricultural $\mathrm{P}$, only a limited number of studies directly compared organic and conventional production systems in this regard (Table 1). The few studies attempting to compare P leaching between the opposing systems found either inconclusive results or that levels of $\mathrm{P}$ leachate are comparatively small. Although P surpluses have been noted among both organic and conventional soils, organically managed fields may be better at governing nutrient cycling and reduce $P$ loss, due to the greater microbial biomass of soils under organic management.

Organic fertility practices, although not without flaws, promote system sustainability by fostering a healthy soil environment through tilth building, creation of organic matter, and increased microbial activity. Taking into account the current data as well as the fact that $\mathrm{P}$ is a limited, non-renewable resource, it is essential to improve its management to reduce $P$ surplus and increase long-term sustainability of food production. Improving soil quality can also lead to soil conservation and reduce the economic and energy costs associated with mineral fertilizers. Therefore, the long-term environmental impact of crop production, due to nutrient loss and leaching, can also be decreased with the implementation of organic fertility practices, further improving sustainability of the system. 


\subsection{Pest Management}

In most cases, a system under conventional management is subjected to a scheduled regime of chemical controls meant to reduce pest (insect, pathogen, and weed) pressures that limit yield and product quality. According to the most recent data (2012), global pesticide usage totaled 5.8 billion pounds, with the U.S. accounting for $23 \%$ and nearly all of which is applied in the agricultural sector [38]. Globally and in the U.S., herbicides account for $50 \%$ of total pesticide usage and have been sharply increasing, while the use of insecticides and fungicides have remained relatively consistent [38]. A handful of studies consistently found conventionally grown fruit and vegetables had more pesticide residues than organic samples (Table 2 and references within). Although the same yield limiting pressures exist in organic systems, the use of most synthetic chemicals is strictly prohibited, leaving producers with only a few effective cultural, mechanical, or physical methods for pest control. These strategies, when integrated with other practices common to organic system management can improve the sustainability by reducing the reliance on harsh chemicals or energy expensive agents for pest control.

Table 2. Comparative Studies on Pest Management (in chronological order).

\begin{tabular}{|c|c|}
\hline Citation & Major Conclusions \\
\hline \multirow{2}{*}{ Phelan et al., 1995 [39] } & $\begin{array}{l}\text { Higher levels of European corn borer (ECB) oviposition on corn plants } \\
\text { were found in conventional soil than organic. }\end{array}$ \\
\hline & $\begin{array}{l}\text { Soil-fertility history was strongly correlated with acceptability of corn } \\
\text { plants to ECB. }\end{array}$ \\
\hline \multirow{2}{*}{ Barberi et al., 1998 [40] } & $\begin{array}{l}\text { Weed seedbank size was greater under the organic system compared to } \\
\text { the conventional, } 100,761 \text { and } 27,601 \text { seeds } \mathrm{m}^{-2} \text {, respectively. }\end{array}$ \\
\hline & $\begin{array}{l}\text { Amaranthus retroflexus and Solanum nigrum were characteristic of the } \\
\text { organic system. }\end{array}$ \\
\hline \multirow[b]{2}{*}{ Clark et al., 1999 [41] } & Weed abundance was highest in organic than conventional systems. \\
\hline & $\begin{array}{l}\text { Weed biomass at harvest was similar in both systems for three out of } \\
\text { four seasons. }\end{array}$ \\
\hline \multirow{2}{*}{ Letourneau and Goldstein, 2001 [42] } & $\begin{array}{l}\text { Arthropod damage to leaves and fruit were similar in commercial } \\
\text { tomatoes produced under organic and conventional management. }\end{array}$ \\
\hline & $\begin{array}{l}\text { Higher abundance of natural enemies and greater species richness of all } \\
\text { functional arthropod groups in organic systems than conventional. }\end{array}$ \\
\hline \multirow{2}{*}{ Abbasi et al., 2002 [43] } & $\begin{array}{l}\text { Anthracnose was reduced in organic fields with a high rate of cannery } \\
\text { compost applied than conventional systems. }\end{array}$ \\
\hline & $\begin{array}{l}\text { Populations of bacterial spot were lower in organic than } \\
\text { conventional systems. }\end{array}$ \\
\hline \multirow[t]{2}{*}{ Baker et al., 2002 [44] } & $\begin{array}{l}\text { Across eight fruits and } 12 \text { vegetables, } 73 \% \text { of the conventionally grown } \\
\text { produce tested positive for pesticide residue compared to } 23 \% \text { of the } \\
\text { organic samples. }\end{array}$ \\
\hline & $\begin{array}{l}\text { More than half of the conventionally produced foods tested positive for } \\
\text { more than one pesticide. }\end{array}$ \\
\hline \multirow{2}{*}{ Bulluck and Ristaino, 2002 [9] } & $\begin{array}{l}\text { Disease incidence level of Sclerotium rolfsii was } 67 \% \text { in soils receiving } \\
\text { synthetic fertilizers while } 3 \% \text { and } 12 \% \text { for soils treated with composted } \\
\text { cotton-gin trash and manure, respectively. }\end{array}$ \\
\hline & $\begin{array}{l}\text { Fusarium spp. decreased with time in soils amended with manure and } \\
\text { were higher at harvest in soil receiving synthetic fertilizer. }\end{array}$ \\
\hline Bulluck et al., 2002 [45] & $\begin{array}{l}\text { Propagule densities of Phytophthora spp. and Pythium spp. were lower in } \\
\text { soil with organic than synthetic fertility amendments. }\end{array}$ \\
\hline
\end{tabular}


Table 2. Cont.

\begin{tabular}{|c|c|}
\hline Citation & Major Conclusions \\
\hline \multirow{2}{*}{ Poudel et al., 2002 [11] } & $\begin{array}{l}\text { Greater weed pressure was found in organic than conventional systems in } \\
\text { both tomato and corn fields. }\end{array}$ \\
\hline & $\begin{array}{l}\text { Organic tomato systems cost } \$ 571 \mathrm{ha}^{-1} \text { for weed management while } \\
\text { conventional systems cost } \$ 420 \mathrm{ha}^{-1} \text {. }\end{array}$ \\
\hline \multirow[b]{2}{*}{ Moonen and Barberi, 2004 [46] } & $\begin{array}{l}\text { Seedbank density was five times greater in systems using no-till and cover } \\
\text { crops compared to conventional tillage practices. }\end{array}$ \\
\hline & $\begin{array}{l}\text { The seedbank of soil under conventional tillage consisted of } 6 \% \text { monocot } \\
\text { seeds and for } 70 \% \text { of annual species while no-till contained } 25 \% \text { and } \\
41 \% \text {, respectively. }\end{array}$ \\
\hline \multirow{2}{*}{${ }^{*}$ Bengtsson et al., 2005 [13] } & $\begin{array}{l}\text { Organic system management increased species richness of birds, insects, } \\
\text { and weeds. }\end{array}$ \\
\hline & $\begin{array}{l}\text { Birds, predatory insects, and soil organisms were found to be } 50 \% \text { more } \\
\text { abundant in organic than conventional systems. }\end{array}$ \\
\hline \multirow{2}{*}{ Pimentel et al., 2005 [15] } & $\begin{array}{l}\text { The herbicides atrazine and metolachlor were detected in water leachate } \\
\text { collected from conventional systems. }\end{array}$ \\
\hline & $\begin{array}{l}\text { In fields where corn followed corn and atrazine was applied two years in } \\
\text { a row, the leachate had atrazine exceeding } 3 \mathrm{ppb} \text {. }\end{array}$ \\
\hline Liu et al., 2007 [22] & $\begin{array}{l}\text { The final incidence of Southern blight was significantly lower in soils from } \\
\text { organic than conventional farms. }\end{array}$ \\
\hline \multirow{2}{*}{ Liu et al., 2007 [47] } & $\begin{array}{l}\text { Incidence of Southern blight was significantly reduced in tomato crops } \\
\text { produced using organic fertility amendments compared to mineral } \\
\text { fertilizer, } 9.7 \% \text { and } 13.7 \% \text {, respectively. }\end{array}$ \\
\hline & $\begin{array}{l}\text { The rate of disease progression was also reduced under with the use of } \\
\text { organic fertility amendments compared to synthetic fertilizer. }\end{array}$ \\
\hline \multirow{2}{*}{ Abouziera et al., 2008 [48] } & $\begin{array}{l}\text { Weed biomass was reduced using organic management compared } \\
\text { to glyphosate. }\end{array}$ \\
\hline & $\begin{array}{l}\text { Black plastic mulch of } 150 \text { or } 200 \mu \mathrm{m} \text { thickness resulted in the greatest } \\
\text { weed control. }\end{array}$ \\
\hline \multirow{2}{*}{ Birkhofer et al., 2008 [23] } & $\begin{array}{l}\text { Bacterivorous nematodes and earthworms were most abundant in fields } \\
\text { receiving organic fertility amendments compared to mineral fertilizer } \\
\text { applications. }\end{array}$ \\
\hline & $\begin{array}{l}\text { Mineral fertilizers were harmful to enchytraeids and Diptera larvae, while } \\
\text { aphids benefited. }\end{array}$ \\
\hline Liu et al., 2008 [49] & $\begin{array}{l}\text { Final disease incidence of Phytophthora capsici was greater in soils with } \\
\text { rye-vetch green manure compared to other organic fertility amendments } \\
\text { and synthetic fertilizer. }\end{array}$ \\
\hline Krauss et al., 2010 [50] & $\begin{array}{l}\text { Weed density, cover, and biomass were } 2-5 \text { times greater in soils with } \\
\text { reduced than conventional tillage. }\end{array}$ \\
\hline Vakali et al., 2011 [51] & $\begin{array}{l}\text { Weed biomass increased with non-inversion than inversion tillage } \\
\text { practices in barley fields, however in rye fields, tillage practice was } \\
\text { insignificant. }\end{array}$ \\
\hline \multirow[b]{2}{*}{ * Baranski et al., 2014 [52] } & $\begin{array}{l}\text { Occurrence of pesticide residues were } 4 \text { times higher in conventional } \\
\text { crops, and contained greater Cd concentrations. }\end{array}$ \\
\hline & $\begin{array}{l}\text { Conventional fruits had a greater frequency of residue detection than } \\
\text { conventional vegetables, } 75 \% \text { and } 32 \% \text { respectively, compared to the } \\
\text { organic crops types where contamination was similar among groups, } 11 \% \text {. }\end{array}$ \\
\hline Birkhofer et al., 2014 [53] & $\begin{array}{l}\text { The bird family Columbidae, the ground beetle subfamily Pterostichinae, } \\
\text { and butterfly subfamilies Heliconiinae and Polyommatinae were more } \\
\text { species-rich in locations under organic compared to conventional systems. }\end{array}$ \\
\hline
\end{tabular}


Table 2. Cont.

\begin{tabular}{|c|c|}
\hline Citation & Major Conclusions \\
\hline \multirow[t]{2}{*}{ Murrell and Cullen, 2014 [54] } & $\begin{array}{l}\text { European corn borer larvae development time was slower on crops } \\
\text { receiving organic systems compared to crops from conventional and } \\
\text { hybrid systems. }\end{array}$ \\
\hline & Plant tissues differed in $\mathrm{S}, \mathrm{Fe}$, and $\mathrm{Cu}$ content due to fertility amendments. \\
\hline \multirow{2}{*}{ * Tuck et al., 2014 [55] } & $\begin{array}{l}\text { Meta-analysis found that arthropods, birds, and microbes showed } \\
\text { significant positive response to organic farming. }\end{array}$ \\
\hline & $\begin{array}{l}\text { Organic production practices increase biodiversity by } 33 \% \text { relative to } \\
\text { conventional practices. }\end{array}$ \\
\hline \multirow{3}{*}{ Clifton et al., 2015 [56] } & $\begin{array}{l}\text { Greater occurrence of entomopathogenic fungi was found in organically } \\
\text { farmed soils, however differences between seasons were recorded. }\end{array}$ \\
\hline & $\begin{array}{l}\text { Abundance of Metarhizium anisopliae colony forming units (CFU) in } \\
\text { organic was significantly higher than conventional systems. }\end{array}$ \\
\hline & $\begin{array}{l}\text { Herbicide and fungicide application did not significantly reduce the } \\
\text { number of viable conidia of Metarhizium spp. }\end{array}$ \\
\hline \multirow{2}{*}{ Feber et al., 2015 [57] } & $\begin{array}{l}77 \% \text { more individuals and } 36 \% \text { more hunting spider species were } \\
\text { collected from organic systems. }\end{array}$ \\
\hline & $\begin{array}{l}\text { No difference in populations of web-building spiders were found } \\
\text { between systems. }\end{array}$ \\
\hline
\end{tabular}

\subsubsection{Insecticides and Fungicides}

Despite the lack of intensive chemical applications, the collective body of data suggests herbivore damage was often similar between organic and conventional fields (Table 2). The data pool also indicates that species richness and abundance, including birds, predators and parasites, as well as arthropods, were greater in organic systems compared to the conventional counterpart. Several studies have focused on describing how insect populations respond to crops fertilized under opposing production systems (Table 2). Populations of several pest species (aphids, flea beetles, and European corn borer) responded specifically to the higher $\mathrm{N}$ tissue concentration common to crops produced with mineral fertilizer than under organic fertility management, although this may not be the response of all pests on all crops.

Additionally, reduced disease incidence was reported in organic fields compared to neighboring conventional fields for several major crop pathogens including Anthracnose and Southern blight (Table 2). The data pool further suggests that the lower pathogen incidence of organic systems is due to increased populations of beneficial soil fungi and fungal-feeding nematodes as consequence of the addition of organic fertility amendments. Various composted materials (plant debris, manure, cotton gin trash) common to organic systems decreased the presence of several yield-reducing pathogens compared to synthetic fertilizers (Table 2). The high competition-sensitivity of certain species, such as Fusarium, suggests that fungi are unable to compete with the increased microbial diversity of soils receiving organic soil amendments, which leads to a reduced disease incidence in the field. Even though there is recurring evidence that organic fertility amendments increase disease suppression, it must be clarified that no single soil additive has shown significant disease suppression against all pathogens and that a pathogen may not behave similarly with all organic fertility amendments [58-60]. Additionally, the increased biodiversity, in both the surrounding landscape and soil common under organic management acts as a form of biological compensation for heavy insecticide and fungicide use. The removal of harsh chemicals not only reduces the environmental impact of the system but also lowers the significant cost associated with agricultural chemicals as well as the likelihood of intoxication of farm workers and community members. 
As questions regarding worker safety and environmental health are raised, it is suspected that a few organically approved pesticides, particularly rotenone (insecticide) and copper (fungicide) based products, might to subjected to further scrutiny. Indeed, the lack of consistent data and evidence suggesting its safety to consumers, specifically its connection with neurological diseases and persistence on food crops after treatment, may potentially lead the organically approved status of rotenone to being challenged $[61,62]$. Copper based products have also been questioned due to their potential to negatively affect the environment. Accumulation of copper in the soil horizons from frequent applications, particularly in orchard operations, has been shown to decrease populations of soil fauna and the associated nutrient cycling and bioturbation, subsequently altering the physical and chemical properties, reducing crop yield, as well as increasing contamination of runoff water [63-66]. Although some negative aspects exist for a small number of organic insecticides and fungicides, improvements in dispersal technology and formulation, as well as increasing the preharvest interval, organically produced agricultural goods that meet consumer expectations can be delivered to market while maintaining the sustainability of the system.

\subsubsection{Herbicides}

Weed management after crop establishment is considerably different between organically and conventionally managed systems. In conventional systems, chemical herbicides are relied upon to reduce weed populations. A USDA report on pesticide use indicates that the top five active ingredients found in herbicides (glyphosate, atrazine, acetochlor, metolachlor, and 2,4-D) are more heavily applied than any other chemical pesticides used in U.S. agriculture [67]. Globally, the use of glyphosate in agriculture has exploded since the release of herbicide tolerant (HT) crops in the mid-1990s, rising from 113 million pounds (51 million $\mathrm{kg}$ ) in 1995 to 1.65 billion pounds (748 million kg) in 2014 (Figure 6) [68]. The U.S. Environmental Protection Agency (EPA) report further states that the usage of glyphosate doubled from 2001 to 2008 in the U.S., from 90 to 180 million pounds, respectively [69]. This same timeframe corresponds to the most drastic surge in HT corn cropping, as well as the continued steady incline in the adoption of HT cotton and soybean in the U.S. [70]. In the U.S., the proportion of HT crop lands have increased from 10\% for corn and cotton, and 17\% for soybean in 1996 to $89 \%$ and $94 \%$ in 2014, respectively; on which 250 million pounds (113 million $\mathrm{kg}$ ) of glyphosate were applied, $49 \%$ on soybean crops alone [68,70]. Although chemical herbicide applications offer an effective method of weed control in conventional systems, they come with significant unsustainable environmental impacts, including herbicide leaching. As of recently, a growing body of evidence has emerged indicating application of glyphosate negatively impacts soil microbial and earthworm populations [71,72]. At the Rodale Institute Farming Systems Trial (FST), Pimentel et al. [15] detected atrazine and metolachlor in water leachate only from fields under conventional weed control. In conventional fields where corn followed corn, detectable atrazine levels were over 3 ppb, the U.S. EPA maximum contaminant level for drinking water [15].

Without the use of efficient chemical controls, organic producers are left with only physical and cultural practices to reduce weed persistence. The current body of evidence consistently suggests greater weed pressure in fields under organic management (Table 2). Furthermore, the data indicate that weed seedbank density of organic fields are significantly greater than in conventional fields, likely a consequence of animal grazing or manure applications which can act as a source of viable weed seeds. Unfortunately, many accepted organic practices carry a higher risk of incomplete weed removal (further adding to seed bank), resulting in lower long-term efficiency, potentially decreasing the sustainability of the system. Intensive inversion tillage practices common to modern agriculture are usually performed with a moldboard plow for effective mechanical destruction and vertical distribution of weed seeds into deep soil horizons. Although an effective means to reduce weed pressure, the deep mechanical manipulation can negatively impact the physical, chemical, and biological characteristics of the soil, as well as higher susceptibility to erosion (wind and water) and reduced crop performance. Inversion tillage is permissible under organic regulations, however 
since it is counterproductive to soil building, many producers have transitioned to low-intensity, non-inversion conservation tillage or no-till practices aiming to conserve soil moisture, reduce erosion, decrease energy and costs, while maintaining weed biomass at acceptable levels. Several studies demonstrated that non-inversion tillage methods significantly improve soil aggregate stability and fertility compared to inversion methods (Table 2), with the most pronounced effects during season with high precipitation. Conservation tillage practices, when coupled with other cultural methods including utilization of cover crops and mulches, are effective at reducing weed seed bank density and subsequent weed pressure. The data further suggest that the method of primary tillage and growing region can influence cover crop performance, therefore finding the appropriate cover crop varieties or combinations can improve soil coverage and efficacy of weed suppression.

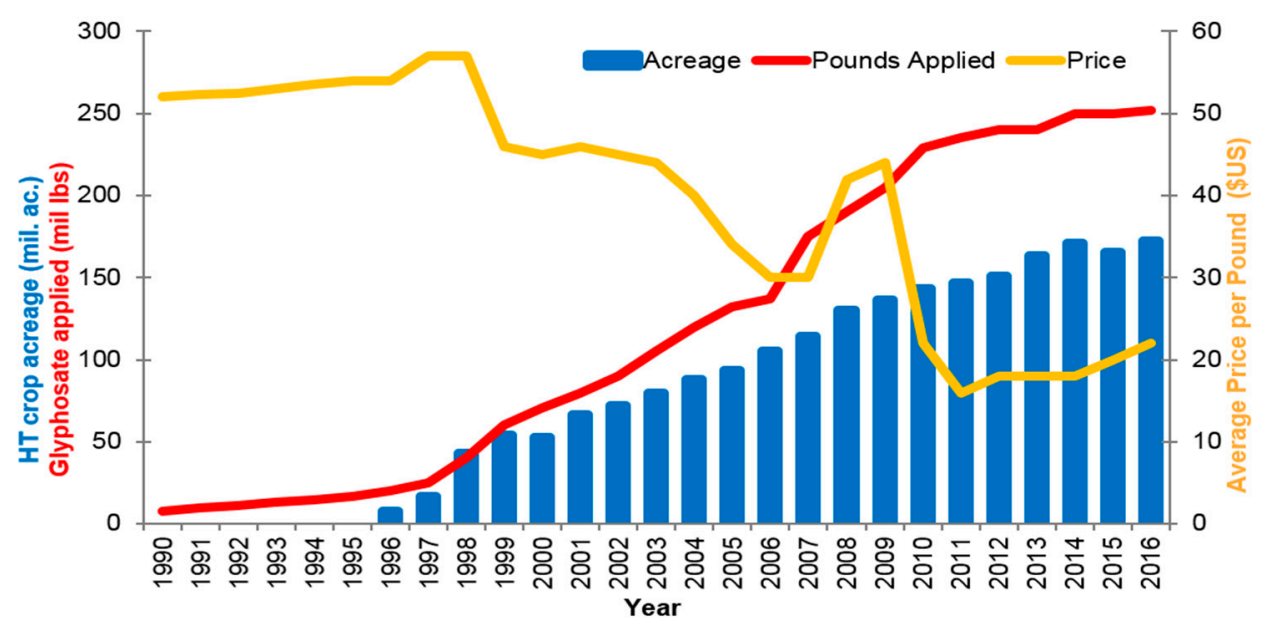

Figure 6. Changes in global glyphosate usage and cost related to the production of herbicide tolerant (HT) crops. Data compiled from Fernandez-Cornejo and Wechsler [70], Benbrook [68], and the USDA-NASS June Agricultural Survey [73] illustrate that, with the commercial release of HT crops (corn, cotton, and soybean) beginning in 1996, the global usage of glyphosate has increased proportionally. The graph also shows how the price of glyphosate fluctuated during the same period. More recently, the price of glyphosate has reached new lows which could be attributed to a combination of multiple factors including a plateau in the planting of HT crops, and the rise in tolerant weeds.

Although acceptable weed control has been demonstrated with the use of cover crops, this strategy might not be appropriate for all fields or crops. Commonly, conventional and organic producers resort to mulching materials (plastic film, straw, paper, woven biodegradable material, and municipal green waste) to reduce the presence of weeds. Multiple studies have shown significant reductions in weed biomass with mulches (black plastic and straw) compared to glyphosate applications by late season under several diverse crop species (Table 2). Polyethylene (PE) plastic mulch has been commonly utilized for decades due to its durability and effectiveness to maintain low weed populations, however several negative environmental aspects associated with its removal and disposal have many organic producers opting for alternative materials. Removal, even with machinery, is time consuming and often results in breakage and small fragments that remain in the soil or end up as water polluting particles. Additionally, the recycling of PE agricultural products, especially the low-density forms, can be difficult due to transportation costs coupled with soil and chemical contaminants present after harvest. Therefore, the majority of agricultural PE is unsustainably discarded into local landfills. Even though weed control under organic management requires a well-thought integrated plan, often with reduced efficacy compared to conventional methods, it has reduced environmental impact and exposes workers less to toxic chemicals, ultimately improving the sustainability of the production system. 


\subsection{Energy Use and Efficiency}

Currently, we are experiencing a monumental time in history as the global population continues to grow concurrently with declines in finite natural resources. To meet the growing food demands of the swelling population, energy conscientious production of agricultural goods has become paramount. Historically, the energy demand of agriculture was of less significance, when many farming operations were low-input by default compared to those of modern times. Over the past 75 years the farming landscape has drastically changed, with modern agriculture relying heavily on off-farm inputs and machinery, in turn increasing both the direct and indirect forms of energy required for production. This approach emanates questions as we navigate a time of increased food demand and declining resources. As the food needs of the future are addressed, the land use and labor force as well as the (direct and indirect) energy load required for conventional and organic systems need to be evaluated and managed sustainably.

\subsubsection{Land and Labor}

Land availability and use efficiency are points often raised by opponents of organic agriculture who question its ability to adequately contribute to feeding the growing population. Even though there are some inconsistencies in determining the exact amount of agricultural land available, the Food and Agriculture Organization (FAO) estimates that $11 \%$ (1.6 billion ha) of the global surface is under agricultural production. It has also been estimated that an additional 2.4 billion hectares have marginal agricultural potential, suggesting that there still is some room for expansion [74,75]. Separate meta-analyses revealed that organic farming requires roughly $85 \%$ more land than conventional systems, coupled with reduced yields, results in a system with reduced land use efficiency (Table 3 and references within). The increased land requirement is largely due to lower crop and livestock yields as well as the extra land required for soil building and breaking of disease cycles.

Table 3. Comparative Studies on Energy Consumption between Organic and Conventional Cropping Systems (in chronological order).

\begin{tabular}{|c|c|}
\hline Citation & Major Conclusions \\
\hline \multirow{3}{*}{ Pimentel et al., 2005 [15] } & Organic system required 35\% more labor than conventional systems. \\
\hline & $\begin{array}{l}\text { Significantly less energy was used to produce corn in organic than } \\
\text { conventional systems, } 3.6 \text { and } 5.2 \text { million } \mathrm{kcal} \mathrm{ha}^{-1} \text {, respectively. }\end{array}$ \\
\hline & $\begin{array}{l}\text { The required energy input of soybean production was similar between } \\
\text { systems: } 2.2 \text { million } \mathrm{kcal} \mathrm{ha}^{-1} \text {. }\end{array}$ \\
\hline \multirow{4}{*}{ Hoeppner et al., 2006 [76] } & $\begin{array}{l}\text { Total energy consumption was } 2.5 \text { times greater under conventional } \\
\text { compared to organic system management. }\end{array}$ \\
\hline & $\begin{array}{l}\text { The use of } \mathrm{N} \text { fertilizer accounted for roughly } 47 \% \text { of the total energy } \\
\text { consumption in conventional systems, however this depended on } \\
\text { the rotation. }\end{array}$ \\
\hline & $\begin{array}{l}\text { Energy output was significantly higher from wheat and flax produced in } \\
\text { conventional systems compared to organic. }\end{array}$ \\
\hline & $\begin{array}{l}\text { Energy efficiency was } 40 \% \text { greater in organic systems due to the lower } \\
\text { energy output. }\end{array}$ \\
\hline \multirow{3}{*}{ Pimentel, 2006 [77] } & $\begin{array}{l}31 \% \text { less total energy input was needed for corn produced organic compared } \\
\text { to conventional production systems. }\end{array}$ \\
\hline & $\begin{array}{l}\text { Direct energy consumption for corn was similar between systems for fossil } \\
\text { fuels ( } 89 \mathrm{~L} \text { diesel and } 40 \mathrm{~L} \text { gasoline) and electricity }\left(13 \mathrm{kWh} \mathrm{ha}^{-1}\right) .\end{array}$ \\
\hline & $\begin{array}{l}\text { The differences in indirect energy consumption between systems was } \\
\text { attributed to the use of commercial fertilizer nutrients and pesticides. }\end{array}$ \\
\hline
\end{tabular}


Table 3. Cont.

\begin{tabular}{|c|c|}
\hline Citation & Major Conclusions \\
\hline \multirow{2}{*}{ Wood et al., 2006 [78] } & $\begin{array}{l}\text { Organic production had reduced indirect energy use than conventional } \\
\text { production due to large exclusion of off-farm products such as mineral } \\
\text { fertilizer and pesticides. }\end{array}$ \\
\hline & $\begin{array}{l}\text { Employment intensity for organic horticultural crops was greater compared } \\
\text { to conventional system, while livestock operations can be lower. }\end{array}$ \\
\hline * Mondelaers et al., 2009 [25] & $\begin{array}{l}\text { Organic systems had } 83 \% \text { land use efficiency compared to } \\
\text { conventional operations. }\end{array}$ \\
\hline \multirow{3}{*}{ * Tuomisto et al., 2012 [26] } & Organic farming requires $84 \%$ more land than conventional operations. \\
\hline & $\begin{array}{l}\text { Organic systems energy consumption was } 21 \% \text { lower than } \\
\text { conventional systems. }\end{array}$ \\
\hline & $\begin{array}{l}\text { High energy inputs of conventional farming were mainly due to } \\
\text { manufacturing and transportation of mineral fertilizers, especially } \mathrm{N} \text {. }\end{array}$ \\
\hline \multirow{5}{*}{ Pergola et al., 2013 [79] } & $\begin{array}{l}\text { Total energy used was higher in conventional orange and lemon production } \\
\text { than organic systems, } 39 \% \text { and } 51 \% \text {, respectively. }\end{array}$ \\
\hline & $\begin{array}{l}\text { Direct energy consumption was greater in lemon produced under organic } \\
\text { practices than conventional, but similar for organic and conventional oranges. }\end{array}$ \\
\hline & $\begin{array}{l}\text { Conventional citrus crops consumed greater indirect energy, largely due to } \\
\text { production and transportation of fertilizer and pest control, than } \\
\text { organic systems. }\end{array}$ \\
\hline & $\begin{array}{l}\text { Human labor was similar between systems for both orange and lemon, } \\
\text { averaging } 53,900 \mathrm{MJ} \mathrm{ha}^{-1} \text {. }\end{array}$ \\
\hline & $\begin{array}{l}\text { Conventional citrus production had a greater reliance on non-renewable } \\
\text { energy than organic systems, } 3.8 \text { and } 2.4 \text { million } \mathrm{MJ} \mathrm{ha}^{-1} \text {, respectively. }\end{array}$ \\
\hline \multirow{4}{*}{ dal Ferro et al., 2017 [80] } & $\begin{array}{l}\text { Total energy input was reduced in organic systems compared to conventional, } \\
12,966 \text { and } 20,968 \mathrm{MJ} \mathrm{ha}^{-1} \mathrm{y}^{-1} \text {. }\end{array}$ \\
\hline & $\begin{array}{l}\text { Fertilization accounted for } 53.7 \% \text { of the energy consumed by conventional } \\
\text { compared to organic production, } 15.5 \% \text {. }\end{array}$ \\
\hline & $\begin{array}{l}\text { Mechanical operations required more energy in organic systems compared to } \\
\text { conventional. }\end{array}$ \\
\hline & $\begin{array}{l}\text { Productivity of the energy invested was greater in organic (4.53) than } \\
\text { conventional operations (4.28). }\end{array}$ \\
\hline \multirow{2}{*}{ Kamali et al., 2017 [81] } & $\begin{array}{l}\text { Organic systems used } \sim 30 \% \text { less energy per ton of soybeans compared to } \\
\text { conventional systems. }\end{array}$ \\
\hline & $\begin{array}{l}\text { Organic systems had higher employment compared to conventional systems, } \\
\text { requiring } 3.98 \text { and } 0.27 \mathrm{~h} \mathrm{ha}^{-1} \text { day }^{-1} \text {, respectively. }\end{array}$ \\
\hline \multirow{2}{*}{ Lin et al., 2017 [82] } & $\begin{array}{l}\text { Higher indirect energy inputs in conventional compared to organic systems } \\
\text { were due to the use of mineral fertilizers and pesticides. }\end{array}$ \\
\hline & $\begin{array}{l}\text { Direct energy consumption was greater among the organic systems due to the } \\
\text { higher diesel usage. }\end{array}$ \\
\hline
\end{tabular}

With a greater land requirement characteristic of organic systems, there will likely be a concurrent need for increased labor. Data from several long-term farming trials suggest that organic systems require $15-35 \%$ more labor than the conventional counterpart, depending on the crop (Table 3). This can be attributed to several factors including greater crop diversity as well as use of mechanical methods to control pests compared to the chemical practices of conventional systems. The labor required for organic operations is consistent over the entire season (spring, summer, and fall) and includes time dedicated to soil quality building, unlike conventional systems where the heavy workload is concentrated to planting and harvesting, ultimately resulting in similar workforce. Interestingly, when comparing 
all forms of energy inputs used in organic and conventional agriculture systems, human labor was the least energy demanding in both. Overall, recent data suggest that the labor required for organic production is greater than for conventional systems. Supporters of expanding organic operations view this as an opportunity to create jobs, especially in developing nations and rural areas where consistent employment is desperately needed, as well as in developed nations, where seasonal farming jobs significantly contribute to job insecurity and wide pay gaps between fulltime and seasonal (often undocumented immigrant) employees.

\subsubsection{Direct and Indirect Energy}

Beside the differences in land and labor use, organic and conventional agricultural systems contrast in the measurable energy consumption required to maintain operations. Energy consumption at a farming systems level can occur both directly and indirectly (Figure 7). Direct energy consumption refers to the use of fossil fuels, lubricants, and electricity while indirect consumption is attributed to manufacturing and distribution of agricultural inputs. It should be cautioned that many studies present energy consumption data without differing direct and indirect use, which can be misleading. To truly understand differences in energy use between farming systems, it is important to identify the points of excessive energy use by examining direct and indirect use independently. This will become necessary in the near future for better management of non-renewable resources and overall improvements in energy use, regardless of the system. Studies comparing direct energy use in organic and conventional systems presented conflicting results. Pimentel [77] determined that the production of organic corn and soy consumed similar amounts of fossil fuels (diesel and gasoline) and electricity as those crops under conventional management. While a recent study conducted in established organic and conventional citrus operations in Italy revealed that direct energy consumption was greater in organic lemons than the conventional counterpart; while on the contrary, organic oranges required less direct energy than those produced conventionally [79]. This indicates that crop type, season length, and production practices can heavily influence the direct energy requirements, regardless of the whole-system management. It should be understood that the direct energy consumption, in both organic and conventional production systems, will expectedly be influenced by the rising cost of fuel and electricity in the future. Exploring the use of renewable energy sources as replacements for non-renewable forms can greatly improve the sustainability of direct energy consumption of all operations. In the future, this paradigm shift will absolutely become critical, as we are faced with concurrent declines in resources and increases in food demand.

Although some variations have been noted in the direct energy consumption between systems, indirect energy consumption has been consistently greater under conventional management (Table 3). A significant portion of the difference in indirect energy consumption between organic and conventional systems can be attributed to the manufacturing of pesticides. Depending on the chemical composition, the manufacturing of pesticides used can be just as energy expensive as $\mathrm{N}$ fertilizer. The specific methods (heating, distillation, and drying) and resources (petroleum products, electricity, and steam) used can also significantly influence the energy requirements for manufacturing a particular pesticide, however the value can be difficult to estimate because these processes are patent protected. Helsel [83] determined that the most common active ingredients (glyphosate, atrazine, acetochlor and metolachlor) of pesticides are among the most energy expensive, requiring 195,200, 81,700 , and 119,000 BTUs/lb, respectively, to manufacture. Product formulation also influences the energy consumption ranging from $8600 \mathrm{BTUs} / \mathrm{lb}$ for emulsified oil and microgranular products to $12,900 \mathrm{BTUs} / \mathrm{lb}$ for wettable powders. Representing only a portion of the indirect energy consumed, the elimination of conventional pesticides can enhance the system sustainability by reducing the reliance on off-farm chemical products manufactured using non-renewable resources and the elimination of associated costs, thus also improving the economic viability.

Of the potential sources for indirect energy consumption, the manufacturing of $\mathrm{N}$ fertilizers is responsible for approximately half of the requirements, making it the single most expensive input of 
modern conventional farming. The production of N-based fertilizers occurs through the Haber-Bosch process, which combines atmospheric $\mathrm{N}$ with hydrogen under high pressure and temperature conditions to form ammonia. Of the $\mathrm{N}$-based fertilizer producers worldwide, $73 \%$ supply $\mathrm{H}_{2}$ to the process through natural gas while $27 \%$ still utilize coal [84]. In general, $\mathrm{N}$ fertilizers produced with the use of either $\mathrm{H}_{2}$ source require a substantial amount of energy to form ammonia, however natural gas is slightly more energy efficient than coal, with 35 and 57 million BTUs required per metric ton $\mathrm{N}_{2}$ utilized, respectively [74]. Since the development of crop varieties with positive yield responses to high $\mathrm{N}$ supplies began in the 1960s, the use of N-based synthetic fertilizers in the U.S. has risen proportionately. In 2010, 10.4 million metric tons of $\mathrm{N}$ fertilizers were applied to crops in the U.S., rising from 2.7 million metric tons in the 1960s, nearly half of which had to be imported to meet the demand [85]. In the U.S., corn is the most fertilizer-dependent crop produced, accounting alone for $46 \%$ of the domestic fertilizer consumption [84]. Based on the current fertilizer consumption rates and energy required for production, coupled with the growing global population, the dependency of N-based fertilizers will increase the agricultural energy demand by more than $45 \%$ [74]. Additionally, the potential rising prices of natural gas, which accounts for $70 \%$ of the cost associated with the production of $\mathrm{N}$ fertilizers, may impact the future usage and could lead to the promotion and increased implementation of organic fertility methods, even in conventional or hybrid operations. Importantly, most of the modern crop varieties have been bred for optimal performance under high-input conditions and unfortunately may not exhibit the same response under reduced $\mathrm{N}$ availability. By creating new or improving existing varieties, especially for crop commodities that are highly dependent on large supplies of N inputs, such as corn and cotton, we will greatly help to reduce the indirect energy consumption of either organic or conventional system, and also improve the management of global finite energy resources while meeting the food demands.

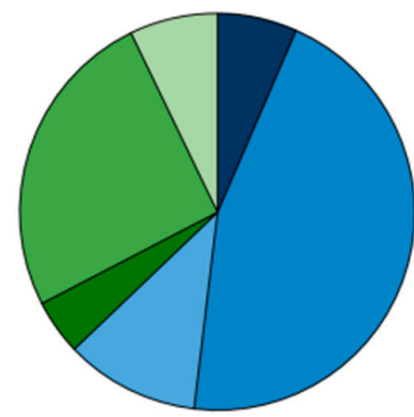

Organic $5850 \mathrm{MJ} \mathrm{ha}^{-1} \mathrm{yr}^{-1}$

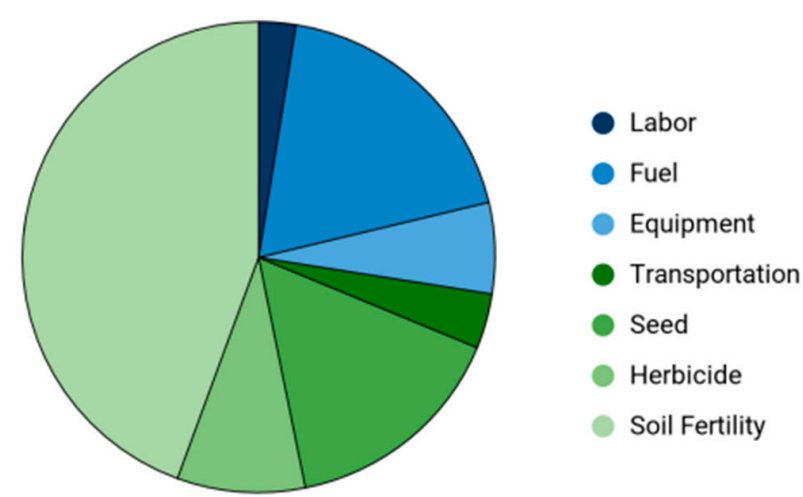

Conventional $8000 \mathrm{MJ} \mathrm{ha}^{-1} \mathrm{yr}^{-1}$

Figure 7. Comparison of energy consumption in organic and conventional systems for annual crops. Data collected from the Rodale Institute long-term FST reveal the differences in energy consumption for fields under organic and conventional management for both indirect and direct forms of energy [15]. Overall, the fields under organic management consumed less energy (represented by the size of the pie chart) than the conventional system. The data also show distinct differences in the forms of energy utilized. Direct energy consumption (labor, fuel, and equipment-indicated in shades of blue) required $63 \%$ of the total energy used in organic systems compared to the $27.5 \%$ demanded in conventional systems. Indirect energy consumption (production and transportation of off-farm inputs, such as seed, soil fertility, herbicide-represented in shades of green) was greatest in conventional systems, accounting for $72.5 \%$ of the total energy required by the system. It should be noted that these data represent annual crop production, and that results are expected to be different for permanent crops. 


\section{Sustainability of Organic Provisions}

Given the increasing interest for organic products, questions concerning the ability of organic systems to meet the current and future global agricultural demand have been raised numerous times. Still a widely debated standpoint, opponents often cite low crop output as the primary constraint limiting the confidence of agricultural stakeholders in the ability of organic systems to meet the population's needs. Although yield is often the only aspect of crop output discussed when comparing whole-system conventional and organic management, there are several other details that should be considered when evaluating the sustainability of the final crop product, including economic performance and nutritional content. Even though multiple production practices advantageous to system health and stability are implemented in organic systems, the lack of understanding in the beneficial characteristics of the final product contribute to the restricted acceptance of organic system management.

\subsection{Yield}

Globally, crop yield is often considered by producers as the most important output. The difference in crop yield between conventional and organic systems has long been regarded as the major issue inhibiting the adoption of organic production practices by both, large and small farmers. Over the years, numerous studies have reported data describing the yield gap between conventional and organic crops, however many of these studies contain factors that could create bias when interpreting the results (Table 4 and references within). Experimental flaws most commonly affecting the validity of early studies comparing system yields included, for example, the use of crop varieties developed for conventional high-input systems, which likely will not exhibit the same superior performance under resource-limited conditions, as well as unbalanced applications of $\mathrm{N}$ between systems. Although several experimental biases are present, the data indicate that crop yield under conventional management is greater than organic systems, especially among grain and horticultural crops (Table 4). Recently, in a meta-analysis of 115 studies where 1071 conventional versus organic comparisons were extracted, Ponisio et al. [86] found organic yields averaging 19\% lower in comparison to conventional crops, a lower gap than previously described and indicative that advancements can be made to further narrow this gap. Significantly greater yields from organic systems have been reported by a small number of studies, particularly for forage (alfalfa, rye, and buckwheat) and hay (perennial and legumes) crops compared to conventional systems. It should be stressed that globally important crops, such as wheat and corn have been given greater breeding attention leading to the development of varieties with superior yield performance under high-input conditions since the Green Revolution than those best suited for organic conditions. Even though much of the yield data produced has varied, the results can be used to identify useful physiological traits and production responses that are adventitious to management to breed superior cultivars specifically created for low-input or organic conditions. Through support and sustained funding, crop varieties that are best suited for growing conditions of systems under organic management with improved yields can be developed.

Table 4. Comparative Analysis on Yield between Organic and Conventional Systems (in chronological order).

\begin{tabular}{cl}
\hline \multicolumn{1}{c}{ Citation } & \multicolumn{1}{c}{ Major Conclusions } \\
\hline & $\begin{array}{l}\text { All crops (tomato, bean, safflower, wheat, oats, corn), except safflower } \\
\text { demonstrated significant yield differences between organic and conventional } \\
\text { systems in at least some years. }\end{array}$ \\
\cline { 2 - 2 } Clark et al., 1999 [87] & \begin{tabular}{l} 
Organic tomato and corn yields were lower in five of the eight years of the study. \\
\cline { 2 - 3 }
\end{tabular} \\
$\begin{array}{l}\text { Yield of bean, wheat, and oats differed less often and tended to vary based on } \\
\text { seasonal environmental conditions. }\end{array}$ \\
\hline
\end{tabular}


Table 4. Cont.

\begin{tabular}{|c|c|}
\hline Citation & Major Conclusions \\
\hline \multirow{2}{*}{ Entz et al., 2001 [88] } & $\begin{array}{l}\text { Grain (wheat, oat, and barley) yields on organic farms were } 77 \%, 73 \% \text {, and } 74 \% \text {, } \\
\text { respectively, of those of conventional farms. }\end{array}$ \\
\hline & $\begin{array}{l}\text { Buckwheat and fall rye yields were similar between systems ( } 97 \% \text { and } 104 \% \text {, } \\
\text { respectively) of conventional yields. }\end{array}$ \\
\hline \multirow{2}{*}{ Mader et al., 2002 [10] } & $\begin{array}{l}\text { Organic potato yields were } 58-66 \% \text { of those in conventional plots, mainly due to } \\
\text { nutrient deficiencies and pathogen pressure. }\end{array}$ \\
\hline & $\begin{array}{l}\text { By the third rotation, organic winter wheat yields had reached } 90 \% \text { of those of } \\
\text { conventional fields, with gradual yield improvement over time. }\end{array}$ \\
\hline \multirow{3}{*}{ Poudel et al., 2002 [11] } & Tomato yield had significant farming system $\mathrm{x}$ year interactions. \\
\hline & $\begin{array}{l}\text { Differences in yield gap between organic and conventional systems were } \\
\text { eliminated by the third season. }\end{array}$ \\
\hline & $\begin{array}{l}\text { In seasons with unexpected production issues (poor emergence, extreme } \\
\text { growing stress), organic tomatoes had } 16 \% \text { greater yield than conventional. }\end{array}$ \\
\hline \multirow{4}{*}{ Pimentel et al., 2005 [15] } & $\begin{array}{l}\text { During the first five years (in a 22-year study), corn grain yields were higher } \\
\text { from conventional than organic system, } 4483 \text { and } 5903 \mathrm{~kg} \mathrm{ha}^{-1} .\end{array}$ \\
\hline & $\begin{array}{l}\text { After the transitional period (Years 1-5), corn grain yield was similar between } \\
\text { systems, } 6451 \mathrm{~kg} \mathrm{ha}^{-1} \text {, during seasons with normal rainfall. }\end{array}$ \\
\hline & Under normal rainfall, soybean yields were similar between systems. \\
\hline & $\begin{array}{l}\text { In seasons under drought conditions, corn and soybean yields were lower in } \\
\text { conventional than organic systems, }-31 \% \text { and }-50 \% \text {, respectively. }\end{array}$ \\
\hline Badgley et al., 2007 [89] & $\begin{array}{l}\text { Modeled organic global food supply data, based on the current agricultural land } \\
\text { use, showed that organic system management can produce enough food on a } \\
\text { global basis per capita. }\end{array}$ \\
\hline \multirow{3}{*}{ Gopinath et al., 2008 [90] } & $\begin{array}{l}\text { Fields receiving mineral fertilizer produced more wheat ears per area than } \\
\text { manure and compost applications. }\end{array}$ \\
\hline & $\begin{array}{l}\text { Wheat produced using mineral fertilizer developed more grains per ear than } \\
\text { those receiving organic fertility amendments. }\end{array}$ \\
\hline & $\begin{array}{l}\text { The yield gap between conventional and organic fields narrowed by the } \\
\text { second season. }\end{array}$ \\
\hline \multirow{3}{*}{ Cavigelli et al., 2009 [91] } & $\begin{array}{l}\text { Corn yield from organic systems increased with increasing crop rotation, } \\
\text { ranging } 41-24 \% \text { less than conventional corn yield. }\end{array}$ \\
\hline & Soybean yield was $19 \%$ lower in organic than conventional systems. \\
\hline & Wheat yield was similar between systems, averaging $4.09 \mathrm{t} \mathrm{ha}^{-1}$. \\
\hline Ri1hi et al., 2009 [92] & $\begin{array}{l}\text { Conventional systems produced greater marketable yield of tomato fruit than } \\
\text { organic systems, } 55.62 \text { and } 34.63 \mathrm{t} \mathrm{ha}^{-1} \text {, respectively. }\end{array}$ \\
\hline \multirow[b]{2}{*}{ * de Ponti et al., 2012 [93] } & On average, organic yields were $80 \%$ of those from conventional operations. \\
\hline & $\begin{array}{l}\text { The relative yield of pre-2004 data was statistically similar to } 2004-2010 \text { data, } \\
\text { indicating the relative yield performance of organic agriculture had not } \\
\text { substantially changed. }\end{array}$ \\
\hline \multirow{5}{*}{ * Seufert et al., $2012[94]$} & $\begin{array}{l}\text { Across several crops, yields from organic systems were on average } 25 \% \text { lower } \\
\text { than conventional. }\end{array}$ \\
\hline & $\begin{array}{l}\text { Organic fruits and oilseed crops demonstrated slightly reduced yields compared } \\
\text { to the conventional counterparts, }-3 \% \text { and }-11 \% \text {, respectively. }\end{array}$ \\
\hline & $\begin{array}{l}\text { Organic cereals and vegetables have significantly lower yields than crops } \\
\text { produced conventionally, }-26 \% \text { and }-33 \% \text {, respectively. }\end{array}$ \\
\hline & $\begin{array}{l}\text { Better organic performance of perennial over annual crops, and legumes over } \\
\text { non-legumes was demonstrated. }\end{array}$ \\
\hline & $\begin{array}{l}\text { The yield gap between organic and conventional crops in developing countries } \\
\text { is greater than in developed countries, }-43 \% \text { and }-25 \% \text {, respectively. }\end{array}$ \\
\hline
\end{tabular}


Table 4. Cont.

\begin{tabular}{|c|c|}
\hline Citation & Major Conclusions \\
\hline \multirow{3}{*}{ Foster et al., 2013 [95] } & $\begin{array}{l}\text { Cotton yield from organic systems was } 42 \% \text { lower than conventional during the } \\
\text { first rotational cycle, while yields were similar in cycle } 2 \text {. }\end{array}$ \\
\hline & Soybean yields were $7 \%$ lower in organic fields than conventional. \\
\hline & $\begin{array}{l}\text { Wheat yield from organic systems was } 37 \% \text { lower than conventional during the } \\
\text { first rotation, but similar thereafter. }\end{array}$ \\
\hline \multirow{2}{*}{ Lee et al., 2015 [96] } & $\begin{array}{l}\text { Marketable yield was higher in conventional than organic onion fields, } 71.5 \text { and } \\
55.8 \mathrm{t} \mathrm{ha}^{-1} \text {, respectively. }\end{array}$ \\
\hline & $\begin{array}{l}\text { Fresh weight of conventional onion }(220.2 \mathrm{~g} / \text { plant }) \text { was greater than organic } \\
\text { onions ( } 175.6 \mathrm{~g} / \text { plant). }\end{array}$ \\
\hline \multirow[t]{2}{*}{ * Ponisio et al., 2015 [86] } & $\begin{array}{l}\text { Meta-analysis determined that organic yields were } 19.2 \% \text { lower than } \\
\text { conventional yields-a smaller yield gap than previously found. }\end{array}$ \\
\hline & Multi-cropping and crop rotation used in organic systems reduced the yield gap. \\
\hline \multirow{4}{*}{ * Kniss et al., 2016 [97] } & Organic yields were lower than conventional yields for most crops. \\
\hline & $\begin{array}{l}\text { Yields for } 9 \text { out of } 13 \text { field and forage crops were significantly less under organic } \\
\text { management than conventional. }\end{array}$ \\
\hline & $\begin{array}{l}\text { Organic hay crops had yields that were similar or greater than conventional } \\
\text { hay crops. }\end{array}$ \\
\hline & $\begin{array}{l}\text { Organic squash, snap bean, sweet maize, and peach yields were similar } \\
\text { to conventional. }\end{array}$ \\
\hline \multirow[b]{2}{*}{ Suja et al., 2017 [98] } & $\begin{array}{l}\text { Similar yield performance of taro under organic and conventional practices, } \\
10.61 \text { and } 11.12 \mathrm{t} \mathrm{ha}^{-1} \text {, respectively. }\end{array}$ \\
\hline & $\begin{array}{l}\text { Yield attributes including cormel number, yield per plant, and weight, and } \\
\text { number of mother corms were similar between conventional and } \\
\text { organic systems. }\end{array}$ \\
\hline
\end{tabular}

The studies reporting yield over the long-term have noted that differences between systems are reduced over time. The data suggest that, during the transitional period (the first three to four years of organic production, which is about the same time required to complete one full crop rotation), organic systems are prone to slimmer yields followed by seasonal increases as the soil quality and microbial populations are restored, after which the yield gap is significantly reduced or no longer existent (Table 4). The meta-analysis conducted by Ponisio et al. [86] further revealed that multicropping and increasing rotation length can further reduce the yield gap between conventional and organic systems by $4-9 \%$. It also should be noted that $\mathrm{N}$-availability in organic systems is driven by the rate of $\mathrm{N}$-mineralization, which is heavily influenced by soil temperatures. Therefore, it is likely that larger yield gaps between systems exist for early-season crops compared to mid- and late-season crops that are planted into warm soils with greater microbial activity. By describing the important crop-soil-microbe interactions that underpin $\mathrm{N}$ availability in organic systems, largely a result of the fertility methods fostering a tightly-coupled $\mathrm{N}$ cycle, it is also possible to select superior varieties that lead to significant reductions in the yield gap between systems. In total, the data indicate how crop yield can be influenced by organic production practices and management, demonstrating that these systems do indeed have potential for producing competitive yields over time. The development of crop varieties with superior yield performance under organic management could positively affect the sustainability by improving the economic viability of the system. However, a renewed interest in the improvement of varieties best adapted to the organic production environment is needed to help close the yield gap in the most efficient manner. 


\subsection{Economic Performance}

Yield is considered the most important output to producers because it is directly related to the economic performance and the ultimate goal of the farming operation, as well as the livelihood of families and communities supported. It is therefore plausible that if the financial performance of organic systems is comparable to those of conventional, then more producers would consider the transition to organic management. The economic performance of a crop, or cropping system, can be estimated by reducing the total cost of agricultural inputs required for production from the current market value of the harvest. Despite the distinctly different input practices, several recent studies indicate that the total costs associated with production were generally similar, differences being attributed mainly to labor and synthetic inputs, particularly mechanical pest control. Comparative analyses focused on the financial competitiveness of production systems found that labor costs were $7 \%$ greater in organic systems, however the increased labor costs were offset by the cost associated with the application of fertilizers and pesticides in conventional systems (Table 5 and references within). It should be noted that labor cost can be influenced by the crop, as well as over the life of long-term perennial crops, therefore contradicting some previously reported data. The increased manpower required for organic production has been also suggested as a means to improve rural stability in the Mediterranean region, Africa, and Latin America, through the redistribution of resources to the underemployed, potentially leading to economic improvements for the surrounding communities, which is difficult to assign a specific value on this social aspect [99].

Table 5. Comparative Analysis of Economic Performance between Organic and Conventional Cropping Systems (in chronological order).

\begin{tabular}{|c|c|}
\hline Citation & Major Conclusions \\
\hline \multirow{7}{*}{ Cavigelli et al., 2009 [91] } & $\begin{array}{l}\text { Average total cost of production for each crop tested (corn, soybean, wheat, } \\
\text { and alfalfa) was greater for conventional compared to organic systems. }\end{array}$ \\
\hline & $\begin{array}{l}\text { For wheat, total production costs were } 29-51 \% \text { greater for conventional than } \\
\text { organic systems which are reflected in the yield gains. }\end{array}$ \\
\hline & $\begin{array}{l}\text { The average price of organic corn, soybean, and wheat was } 122 \% \text { greater than } \\
\text { the conventional product. }\end{array}$ \\
\hline & $\begin{array}{l}\text { When price premiums are applied, annual returns were greater for organic } \\
\text { systems than conventional; without premiums, organic } 4+\text { year rotations and } \\
\text { conventional systems were similar. }\end{array}$ \\
\hline & $\begin{array}{l}\text { Cumulative net returns were } 3-4.5 \text { times greater for organic than the } \\
\text { conventional system. }\end{array}$ \\
\hline & $\begin{array}{l}\text { Organic systems with a 2-year rotation had the greatest net present value } \\
\text { (NPV) and greatest mean return, but also the greatest variability and } 7.5 \text { times } \\
\text { the risk. }\end{array}$ \\
\hline & $\begin{array}{l}\text { Organic systems with a } 4+\text { year rotation had the lowest variability and } \\
\text { associated risk. }\end{array}$ \\
\hline \multirow{2}{*}{ Sandhu et al., 2010 [100] } & $\begin{array}{l}\text { Total economic value of ecosystem services (biological control, soil formation, } \\
\text { mineralization) was higher in organic fields compared to conventional, } \\
\text { averaging US } \$ 232.00 \text { and } \$ 146.00 \mathrm{ha}^{-1} \text { year }^{-1} \text {, respectively. }\end{array}$ \\
\hline & $\begin{array}{l}\text { Economic performance of ecosystem services in conventional fields was } \\
\text { severely reduced due to the use of pesticides. }\end{array}$ \\
\hline \multirow{2}{*}{ Cavigelli et al., 2013 [101] } & $\begin{array}{l}\text { Net returns for organic systems were greater than conventional systems, } \\
\text { US } \$ 286 \text { and } \$ 78 \text { acre }^{-1} \text {, respectively. }\end{array}$ \\
\hline & $\begin{array}{l}\text { The economic risk was greater for conventional than organic systems with the } \\
\text { same rotation length ( } 3 \text { years). }\end{array}$ \\
\hline
\end{tabular}


Table 5. Cont

\begin{tabular}{|c|c|}
\hline Citation & Major Conclusions \\
\hline \multirow{3}{*}{ Forster et al., 2013 [95] } & $\begin{array}{l}\text { Conventional farming systems gained higher gross margins, } 21 \% \text {, during the } \\
\text { first cycle of the 2-year rotation; however organic gross margins were greater } \\
\text { after the second cycle. }\end{array}$ \\
\hline & $\begin{array}{l}\text { Variable production cost of conventional compared to organic farming } \\
\text { systems was higher in cotton, soybean, and wheat, 38\%, 66\%, and } 49 \% \text {, } \\
\text { respectively, due to higher input costs. }\end{array}$ \\
\hline & Labor costs were similar between organic and conventional systems. \\
\hline \multirow{2}{*}{ Pergola et al., 2013 [79] } & $\begin{array}{l}\text { Total life cycle cost of conventional lemon was greater than organic } \\
\text { production, } € 180,533 \text { and } € 178,074 \mathrm{ha}^{-1} \text {, respectively. }\end{array}$ \\
\hline & $\begin{array}{l}\text { Production costs for conventional oranges, } € 154,110 \mathrm{ha}^{-1} \text {, were higher } \\
\text { compared to organic oranges, } € 133,159 \mathrm{ha}^{-1} \text {. }\end{array}$ \\
\hline \multirow{5}{*}{ Mohamad et al., 2014 [102] } & $\begin{array}{l}\text { Initial and future investment of conventional and organic olive operations } \\
\text { were similar. }\end{array}$ \\
\hline & $\begin{array}{l}\text { Soil management costs were higher in organic olives compared to } \\
\text { conventional systems. }\end{array}$ \\
\hline & $\begin{array}{l}\text { Revenues were higher in the organic than conventional systems due to } \\
\text { subsidies and premium price }(+25 \%) \text { applied. }\end{array}$ \\
\hline & $\begin{array}{l}\text { NPV of organic systems of the organic system, } € 16,041 € \text { ha }^{-1} \text {, was } 6 \% \text { greater } \\
\text { compared to the conventional system, } € 15,118 \mathrm{ha}^{-1} \text {. }\end{array}$ \\
\hline & $\begin{array}{l}\text { Internal rate return (IRR) was higher in organic than conventional systems, } \\
3.51 \% \text { and } 3.37 \% \text {, respectively. }\end{array}$ \\
\hline \multirow{5}{*}{$\begin{array}{l}\text { * Crowder and Reganold, } \\
2015[103]\end{array}$} & Organic labor costs were $7 \%$ greater than the conventional system. \\
\hline & $\begin{array}{l}\text { When price premiums are not applied, NPV of organic agriculture was lower, } \\
-27 \text { to }-23 \% \text {, than those of conventional systems. }\end{array}$ \\
\hline & $\begin{array}{l}\text { When premiums are applied, organic systems were } 22-35 \% \text { more profitable } \\
\text { than conventional systems. }\end{array}$ \\
\hline & $\begin{array}{l}\text { Breakeven premium required to match the economic performance of } \\
\text { conventional systems requires premium prices to only be } 5-7 \% \text { greater than } \\
\text { price of the conventional product. }\end{array}$ \\
\hline & $\begin{array}{l}\text { Total costs, gross returns, benefit/cost ratios, and NPV for organic compared } \\
\text { to conventional crops and systems were consistently greater across the } \\
40 \text {-year study period. }\end{array}$ \\
\hline \multirow{2}{*}{ Sgroi et al., 2015 [104] } & $\begin{array}{l}\text { Gross production value of organic lemon operations was substantially greater } \\
\text { than conventional lemon farms, } € 6138.28 \mathrm{ha}^{-1} \text { and } € 648.98 \mathrm{ha}^{-1} \text {, respectively. }\end{array}$ \\
\hline & $\begin{array}{l}\text { Production costs were } 30 \% \text { lower in organic compared to conventional lemon } \\
\text { management. }\end{array}$ \\
\hline \multirow{3}{*}{ Testa et al., 2015 [105] } & $\begin{array}{l}\text { Greater economic convenience in organic lemon production compared to } \\
\text { conventional was due to reduced production costs coupled with price } \\
\text { premiums. }\end{array}$ \\
\hline & $\begin{array}{l}\text { Lemon orchards under organic production had a positive net cash flow by } \\
\text { year six of stand development in comparison to conventional systems, } € 789 \\
\text { and } €-23 \mathrm{ha}^{-1} \text {, respectively. }\end{array}$ \\
\hline & $\begin{array}{l}\text { Conventional systems did not record a positive net cash flow until the } \\
\text { maturity phase (years } 10-42 \text { ), however they were still significantly lower, } \\
€ 402 \mathrm{ha}^{-1} \text {, than the cash flow reported for organic systems during the same } \\
\text { time, } € 1783 \mathrm{ha}^{-1} \text {. }\end{array}$ \\
\hline Bett and Ayieko, 2016 [106] & $\begin{array}{l}\text { NPV was greater for low-input organic farming compared to conventional } \\
\text { systems in Kenya, Kenyan Shilling (KSh) } 22,561 \mathrm{ha}^{-1}\left(€ 275 \mathrm{ha}^{-1}\right) \text { and KSh } \\
21,878 \mathrm{ha}^{-1}\left(€ 267 \mathrm{ha}^{-1}\right) \text {, respectively. }\end{array}$ \\
\hline
\end{tabular}


Table 5. Cont.

\begin{tabular}{cl}
\hline \multicolumn{1}{c}{ Citation } & Major Conclusions \\
\hline Kamali et al., 2017 [81] & $\begin{array}{l}\text { Organic soybeans were more likely to be profitable than both conventional } \\
\text { genetically modified (GM) and non-GM soybean. }\end{array}$ \\
\cline { 2 - 2 } & $\begin{array}{l}\text { Organic system had a greater mean performance of profitability, 11-15\% } \\
\text { higher, than conventional systems, but was associated with higher risk. }\end{array}$ \\
\hline * Indicates a meta-analysis study.
\end{tabular}

The innovative meta-analysis conducted by Crowder and Reganold [103] comparing the global competitiveness of organic agriculture determined that organic systems were significantly more profitable despite lower yields, obtaining $22-35 \%$ greater net present value (NPV) in comparison to conventional systems. Although there were minor differences in the total cost of production inputs between conventional and organic systems, they alone could not account for the economic gains reported. Data comparing the economic performance of individual organic crops are becoming more available, the consensus of which is that organic products are more profitable due to the premium price they achieve in the market (Table 5). Due to this premium, the positive net cash flow is greater in organic systems, while the time required to obtain a positive net cash flow is also reduced. Without the added premium attached to these products, the economic benefits of organic production could be reduced below those of conventional systems. Several recent studies comparing profitability demonstrated that organic systems are more profitable than conventional operations. Consistently greater NPV and income return rate (IRR) have been reported across diverse crops including tree fruit and field crops produced under organic management in comparison to conventional (Table 5). The data indicate that the economic gains received vary based on crop and growing region. Although the organic gains were not always substantial over conventional production, it may provide enough incentive depending on the economic status of the producer, especially for those in developing countries and emerging markets.

Overall, the financial data produced from the various studies illustrate that the economic performance of organic systems is reliant on the premium prices obtained at the market. Currently the price of organic products is generally $30 \%$ greater than those of the non-organic counterparts (Table 5). However, the breakeven premium required to match the economic performance of conventional systems, factoring in the roughly $20 \%$ lower yields of organic fields, requires that premium prices need to only be $5-7 \%$ greater than the price of the conventional product [103]. These data suggest that stability and economic convenience of organic systems is greater than that of conventional operations. The data also show that, even if faced with a reduction in organic premiums as great as $10 \%$, there would still be room for the expansion of organic products in the marketplace. Premium prices are established and maintained by the willingness of the consumer to pay for a product they perceive as sustainably produced, environmentally friendly, nutritious, and pesticide-free. If the expectations of the customer base would ever become compromised, the premiums awarded to organic products could be negatively affected and hence the profitability of organic operations. Therefore, it is important to maintain standards that result in high-quality products to retain consumer confidence. Premium prices significantly larger than breakeven prices, coupled with the potential long-term profitability and other financial benefits offered by organic products should provide enticing incentives to growers to make the transition to organic management.

The transitional period required for organic certification is considered the most financially difficult for producers, not only due to reduced yields (without premiums applied), but also due to expenses often overlooked in economic performance analyses, including the cost of certification, as well as the time required to identify and develop relationships within the market. Although this may be a difficult financial period, making several strategic decisions regarding crop type, crop diversity, and rotational length could reduce the financial burden of organic system 
management during transition (Table 5). Findings indicate that organic four-year rotations, or longer, generated slightly less returns than shorter rotation cycles but also had less economic variability and, thus, were of lower risk. The overall economic performance in the long-term outweighs the burden of transition, making organic management an economically viable investment, contrary to the assumptions of many producers and policy makers.

Many ecological benefits, termed ecosystem services, created from organic management have not been included in most economic analyses largely due to the difficulty in calculating the associated monetary value of species diversity, soil formation, carbon sequestration, as well as reduced erosion and pollution. Although an emerging concept, still faced with many hurdles, the economic benefits associated with ecosystem services provided under organic management are being addressed (Figure 8; Table 5). A recent study conducted in Portugal by Castro e Silva and Silva [107] to evaluate the transition to organic production in the face of climate change determined that the additional carbon sequestration, modeled at 48 million metric tons over a 20-year period (based on long-term data collected in the Rodale Institute FST), should translate into a carbon market value. Although this value may not be enough to entice producers to make the transition to organic system management alone, coupled with the economic benefits of other ecosystem services, it could provide the necessary motivation. The involvement of government delegates and policy makers to develop programs that offer producer support and incentives to operate under certified organic management due to the long-term environmental benefits would also encourage system adoption. The introduction of step-down payments by the Danish government, starting at $412 € \mathrm{ha}^{-1}$, directly to organic producers as a result of the Organic Farming Act (1987) has been very successful at promoting the transition to organic management [108].

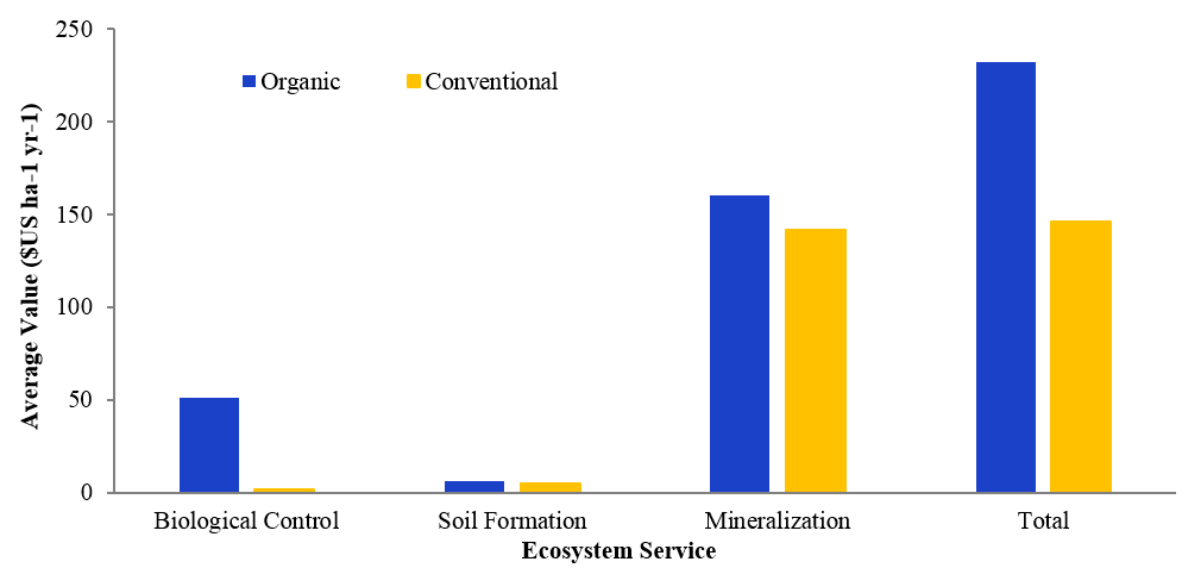

Figure 8. Estimated value of ecosystem services provided by organic system management. Sandhu et al. [100] estimated the economic gain of ecological benefits provided through conventional and organic system management. Each service (biological control, soil formation, and mineralization) was estimated using several parameters and appropriate economic calculations. The data revealed that the total economic value of these services in organic fields was significantly greater than those from conventional fields, with much of the benefits being attributed to the removal of synthetic chemical pesticides.

\subsection{Nutritional Quality}

Although several studies have demonstrated that yields obtained from organic systems are generally reduced, the economic performance is greater than that of conventional systems. The difference in the financial benefits between conventional and organic systems is largely due to the premium prices awarded in the market, which will likely remain the trend as long as the willingness of the consumer to pay continues. This willingness, in part, is due to the belief that organic products are of a higher quality: offering greater nutritional benefits while being free of 
pesticide residue and produced with reduced environmental impact. Crop quality is a complex term that integrates several physiological (firmness, dry matter content) and biochemical (nutritional and sensory) factors, creating great difficulty to generically compare products from conventional and organic systems. Over the years, the pool of data describing differences in specific quality parameters has become quite large. Results have been presented from numerous crops covering multiple quality attributes, various global locations and soil types. Consequently, data variability among studies is high, making it hard to determine whether differences between conventional and organic crops are consistent enough for general statements about the relative dietetic benefits of crops produced from one system over another. Due to poor experimental designs and lack of consistency in the techniques utilized for measuring nutrient components, as well as concerns about the organic definition applied and varieties tested, reports for nutrient analyses prior to the year 2000 have not been considered for this review. In the last decade, several studies have aimed at assessing the differences in the nutritional quality of crops produced in conventional and organic systems (Table 6 and references within). With modern advancements in technology and computing capacity, coupled with consistently accepted organic practices, the mounting pool of data have greater scientific validity and therefore can be used to contrast the sustainability of conventional and organic crops

Table 6. Comparative Analysis of Nutritional Quality Differences between Organic and Conventional Systems (in chronological order).

\begin{tabular}{|c|c|}
\hline Citation & Major Conclusions \\
\hline \multirow{2}{*}{ Carbonaro et al., 2002 [109] } & $\begin{array}{l}\text { Ascorbic and citric acids were higher in organic compared to } \\
\text { conventional peaches. }\end{array}$ \\
\hline & $\begin{array}{l}\text { Greater tocopherol was found in organic pears than those produced under } \\
\text { conventional management. }\end{array}$ \\
\hline Mitchell et al., 2007 [110] & $\begin{array}{l}\text { Tomatoes from organic systems had higher concentrations of the flavonoids } \\
\text { quercetin and kaempferol than those from conventional systems, } 79 \% \text { and } \\
97 \% \text {, respectively. }\end{array}$ \\
\hline \multirow[b]{2}{*}{ * Dangour et al., 2009 [111] } & Nitrogen content was higher in crops from conventional systems than organic. \\
\hline & $\begin{array}{l}\text { Organically produced crops were higher in phosphorus and titratable acidity } \\
\text { than conventional samples. }\end{array}$ \\
\hline \multirow{2}{*}{ Riahi et al., 2009 [92] } & $\begin{array}{l}\text { Soluble solids, } \mathrm{pH} \text {, titratable acidity, and firmness of tomato fruit were } \\
\text { affected by the production system, but the effect depended on the cultivar. }\end{array}$ \\
\hline & $\begin{array}{l}\text { Tomato lycopene and total phenolic contents were similar between organic } \\
\text { and conventional production systems. }\end{array}$ \\
\hline \multirow{3}{*}{ Soltoft et al., 2010 [112] } & $\begin{array}{l}\text { Higher concentration of the phenolic 5-caffeoylquinic acid was detected in } \\
\text { potatoes produced organically. }\end{array}$ \\
\hline & $\begin{array}{l}\text { Higher concentration of nitrogen was detected in conventional carrot } \\
\text { than organic. }\end{array}$ \\
\hline & $\begin{array}{l}\text { No differences were found for any of the analyzed polyphenols between } \\
\text { carrots or onions in organic and conventional systems. }\end{array}$ \\
\hline \multirow{3}{*}{ * Brandt et al., 2011 [113] } & $\begin{array}{l}\text { Organic samples had } 12 \% \text { more secondary metabolites than } \\
\text { conventional samples. }\end{array}$ \\
\hline & Dry matter of organic products was similar to conventional counterparts. \\
\hline & $\begin{array}{l}\text { Vitamin C and all groups of secondary metabolites, except carotene and } \\
\text { non-defense compounds, were higher in organic than conventional samples. }\end{array}$ \\
\hline
\end{tabular}


Table 6. Cont.

\begin{tabular}{|c|c|}
\hline Citation & Major Conclusions \\
\hline \multirow{5}{*}{ Lombardo et al., 2012 [114] } & $\begin{array}{l}\text { Potatoes from organic systems had } 18 \% \text { more total phenolics than those from } \\
\text { conventional systems. }\end{array}$ \\
\hline & $\begin{array}{l}\text { Ascorbic acid content of conventionally produced tubers were } 23 \% \text { greater } \\
\text { than from organic systems. }\end{array}$ \\
\hline & $\begin{array}{l}\text { The nitrate content in organically grown tubers was } 34 \% \text { lower than } \\
\text { conventional products. }\end{array}$ \\
\hline & $\begin{array}{l}\text { Lower soluble sugars and higher dry matter content were observed in } \\
\text { organic potatoes. }\end{array}$ \\
\hline & $\begin{array}{l}\text { Better sensory performance after frying (crispness and less browning) was } \\
\text { observed in potatoes from organic than conventional systems. }\end{array}$ \\
\hline \multirow{3}{*}{ Oliveira et al., 2013 [115] } & $\begin{array}{l}\text { Tomatoes from conventional systems were greater in size (weight and width) } \\
\text { than organic fruit. }\end{array}$ \\
\hline & $\begin{array}{l}\text { Higher soluble solids, total phenolics, citric acid, yellow flavonoids, and total } \\
\text { vitamin } C \text { were detected in organic compared to conventional tomatoes } \\
\text { at harvest. }\end{array}$ \\
\hline & $\begin{array}{l}\text { Phenylalanine ammonia lyase (PAL) activity was } 140 \% \text { higher in organic than } \\
\text { conventional tomatoes at harvest. }\end{array}$ \\
\hline \multirow{5}{*}{ * Baranski et al., 2014 [52] } & $\begin{array}{l}\text { Significantly higher antioxidant activity was detected in organic compared to } \\
\text { conventional fruit samples. }\end{array}$ \\
\hline & $\begin{array}{l}\text { Higher concentrations of total flavonoids, total phenolic acids, flavanones, } \\
\text { stilbenes, flavones, flavonols, kaempferol, and total anthocyanins were found } \\
\text { in organic compared to conventional crops. }\end{array}$ \\
\hline & $\begin{array}{l}\text { Greater concentrations of xanthophyll and vitamin } C \text { were measured in } \\
\text { organic crops, while conventional crops were higher in vitamin E. }\end{array}$ \\
\hline & $\begin{array}{l}\text { Occurrence of pesticide residue was four times greater on conventional than } \\
\text { organic crops. }\end{array}$ \\
\hline & Conventional crops had higher concentrations of total $\mathrm{N}$ and $\mathrm{Cd}$. \\
\hline Brazinskiene et al., 2014 [116] & $\begin{array}{l}\text { Potatoes from organic and conventional systems had similar dry matter, } \\
\text { starch, and phenolic acid content. }\end{array}$ \\
\hline \multirow{5}{*}{ Reganold et al., 2014 [117] } & $\begin{array}{l}\text { Organic strawberries had a longer shelf-life; the loss in fresh weight was } \\
\text { lower than conventional strawberries. }\end{array}$ \\
\hline & $\begin{array}{l}\text { Organic strawberries were } 13.4 \% \text { smaller than conventional fruits, but had } \\
8.3 \% \text { more dry matter. }\end{array}$ \\
\hline & $\begin{array}{l}\text { Organic strawberries had higher antioxidant activity }(8.5 \%) \text {, ascorbic acid } \\
(9.7 \%) \text {, and phenolics }(10.5 \%) \text { than conventional berries. }\end{array}$ \\
\hline & $\begin{array}{l}\text { Greater P }(13.6 \%) \text { and } \mathrm{K}(9.1 \%) \text { were found in conventional strawberries } \\
\text { than organic. }\end{array}$ \\
\hline & $\begin{array}{l}\text { Consumer-sensory panel found organic "Diamante" strawberries sweeter, } \\
\text { with better flavor, appearance, and overall acceptance compared to } \\
\text { conventional "Diamante" berries. }\end{array}$ \\
\hline \multirow{2}{*}{ Vinha et al., 2014 [118] } & $\begin{array}{l}\text { Organically produced tomatoes contained } 17.7 \% \text { more total soluble solids and } \\
30.2 \% \text { less hue angle (i.e., more red pigmentation) than conventional fruits. }\end{array}$ \\
\hline & $\begin{array}{l}\text { Tomato produced from organic systems were higher in ascorbic acid, } \\
\text { lycopene, total phenolics, and flavonoids than those from conventional } \\
\text { systems, } 30 \%, 20 \%, 20 \%, 24 \% \text {, and } 21 \% \text {, respectively. }\end{array}$ \\
\hline \multirow{2}{*}{ Bach et al., 2015 [119] } & $\begin{array}{l}\text { Dry matter content and sugar concentration were similar between organic } \\
\text { and conventional carrots. }\end{array}$ \\
\hline & $\begin{array}{l}\text { No significant differences in sensory quality were found between organic and } \\
\text { conventional cropping systems. }\end{array}$ \\
\hline
\end{tabular}


Table 6. Cont.

\begin{tabular}{|c|c|}
\hline Citation & Major Conclusions \\
\hline \multirow{4}{*}{ Cuevas et al., 2015 [120] } & $\begin{array}{l}\text { Organic plums had } 5-10 \% \text { higher antioxidant capacity than } \\
\text { conventional fruit. }\end{array}$ \\
\hline & $\begin{array}{l}\text { Greater polyphenol and anthocyanin concentrations were detected in organic } \\
\text { compared to conventional plums. }\end{array}$ \\
\hline & $\begin{array}{l}\text { Plums cultivated in organic orchards had higher total organic acid content } \\
\text { than conventional, } 1475 \text { and } 1409 \mathrm{mg} / 100 \mathrm{~g} \text { FW, respectively. }\end{array}$ \\
\hline & $\begin{array}{l}\text { Organic plums had greater concentrations of malic, succinic, tartaric, and } \\
\text { shikimic acids than those from conventional orchards. }\end{array}$ \\
\hline Karlund et al., 2015 [121] & $\begin{array}{l}\text { Chemical composition and sensory qualities of organic and conventional } \\
\text { strawberries vary mostly due to the cultivar. }\end{array}$ \\
\hline \multirow{3}{*}{ Lee et al., 2015 [96] } & $\begin{array}{l}\text { Total phenolics were greater in conventional compared to organic onions, } \\
404.7 \text { and } 378.5 \mathrm{mg} \mathrm{GAE} \mathrm{kg}^{-1} \text {, respectively. }\end{array}$ \\
\hline & $\begin{array}{l}\text { No differences in soluble solid, pyruvic acid, total flavonoids and phenolics } \\
\text { were found between organic and conventional onions. }\end{array}$ \\
\hline & $\begin{array}{l}\text { Bulb diameter and fresh weight were higher in conventional than } \\
\text { organic onion. }\end{array}$ \\
\hline \multirow{2}{*}{ Valverde et al., 2015 [122] } & $\begin{array}{l}\text { Total phenolic and flavonoid contents in broccoli were similar between } \\
\text { organic and conventional systems. }\end{array}$ \\
\hline & Glucosinolate levels were higher in organic than conventional samples. \\
\hline \multirow[b]{2}{*}{ de Pascale et al., 2016 [123] } & Titratable acidity was $20 \%$ higher in conventional than organic tomatoes. \\
\hline & $\begin{array}{l}\text { Lipophilic antioxidant capacity and carotenoid levels were increased under } \\
\text { organic soil fertility management, } 25 \% \text { and } 14 \% \text {, respectively, } \\
\text { then conventional. }\end{array}$ \\
\hline \multirow{3}{*}{ Ren et al., 2017 [124] } & $\begin{array}{l}\text { Flavonol was } 20 \% \text { greater in organic compared to conventional onions for } \\
\text { both varieties tested. }\end{array}$ \\
\hline & $\begin{array}{l}\text { Levels of quercetin and its glycosides in organic onion samples were } \\
\text { consistently greater than conventional onions. }\end{array}$ \\
\hline & $\begin{array}{l}\text { The antioxidant activity of organic onions was higher than those from } \\
\text { conventional systems. }\end{array}$ \\
\hline \multirow{2}{*}{ Suja et al., 2017 [98] } & $\begin{array}{l}\text { Organic taro had higher dry matter, starch, total and reducing sugars than } \\
\text { conventional crops, } 7.29 \%, 10.78 \%, 31.55 \%, 9.37 \% \text {, respectively. }\end{array}$ \\
\hline & $\begin{array}{l}\text { Conventionally produced taro had higher phenol, fiber, and ash content than } \\
\text { taro from organic systems, } 6.04 \%, 19.78 \% \text {, and } 20.07 \% \text {, respectively. }\end{array}$ \\
\hline
\end{tabular}

The recent research, although having greater experimental consistency and using modern technology, is still extremely complex and difficult to simply due to the manners in which the data have been categorially (system, nutritional attribute, crop type, variety) analyzed. Overall, the results indicate significant differences in concentration of several nutritional components between crops from conventional and organic systems (Table 6). Studies have consistently reported that crops from organic systems have higher concentrations of several groups of valued nutrients, including secondary metabolites with antioxidant activity, carotenoids, vitamins, total flavonoids and phenolic acids than those managed conventionally. Few studies have also identified several specific nutritionally desirable compounds, such as anthocyanins as well as some carotenoids and vitamins, such as xanthophyll and ascorbic acid (vitamin C), that consistently appear to be in higher concentration in crops produced organically, while tocopherols (vitamin E) are greater in crops under conventional management. Significant differences for several specific macronutrients, including fiber, amino acids and protein, have been repeatedly found between crops produced under conventional and organic management. Differences in production practices, specifically fertilization methods and restricted pesticide use have 
also been linked to the accumulation of specialized plant metabolites and minerals detected in organic crops (Table 6). Still in its infancy, the global assessment of the nutritional benefits offered by crops produced organically remains difficult to confirm, however the quality and consistency of data recently reported strongly point toward higher concentration of several beneficial nutrients in organic crops. The present data also indicates that not all crops showed a response to system management, and that results might be crop-specific.

An important revelation of the collective data pool was nutritional differences among cultivars produced in organic systems, suggesting genotype-environment interactions. Karlund et al. [121] found that the sensory qualities of strawberries produced under different cultivation systems varied mostly to due to genotype. Cuevas et al. [120] identified one plum variety with superior production of total phenolic compounds and total organic acid content under organic management compared to the other twelve accessions tested. Lombardo et al. [114] also identified a potato variety that presented greater total phenols and ascorbic acid than the other varieties tested when produced under organic practices. Although the pool of data describing nutritional differences between crop cultivars produced in organic systems is relatively small, it does highlight the importance of proper selection and development of varieties with the physiological capabilities suited to thrive in stressed environments that are common to organic systems. The current pool of data also suggests that, by accepting a certain level of environmental stress, superior nutritional components can be obtained.

\section{Breeding for Cropping Sustainability}

Thus far, this review has presented a wealth of data concerning the differences in sustainability of specific management practices between conventional and organic agriculture. In the following, we address the shortcomings of the organic system to further promote global adoption. Crop response to many of the environmental factors that often affect yield in organic systems, such as the availability of $\mathrm{N}$ or water as well as pest infestations, could be improved through the development of varieties with superior performance bred specifically for the organic system.

\subsection{Breeding for Organic Systems}

It is estimated that $95 \%$ of the varieties produced in organic systems were actually selected under high-input conventional practices, likely limiting their ability to perform well under the common stress conditions associated with that environment [125]. Several recent studies have identified specific varieties with superior performance under organic compared to conventional management, suggesting a strong genotype $\mathrm{x}$ environment interaction for tomato, plum, apple, blueberry, strawberry, corn, potato, and wheat $[116,117,120,126-130]$. Although the concept of breeding specifically for organic agriculture is relatively new, several small agricultural companies and public institutions mostly in Europe and North America have initiated breeding programs directed at organic agriculture to help meet the needs of these underrepresented producers (Figure 9). Breeding programs within organic systems can be found in France, Austria, Germany, Switzerland, and the Netherlands, as well as Canada and the U.S., with a focus on a range of horticultural as well as grain crops, including tomato, squash, dry and green beans, peppers, spinach, broccoli, cauliflower, cabbage, onion, carrots, beets, potato, field and sweet corn, barley, winter wheat, and quinoa [131]. Breeding for the target environment allows for alleles and traits particular to organic production to be selected. This same strategy has been extremely successful in leading to the development of a magnitude of superior varieties for modern conventional systems. Breeding of new varieties within organic systems certainly is not a simple task given the complexities of plant traits of interest and environmental factors, however through direct selection the improvement of valuable traits can be achieved, resulting in superior organically adapted varieties. It is also important to consider that seed (genetic) banks harboring thousands of accessions worldwide, including wild relatives, heirlooms, and abandoned landraces can serve as breeding material from which superior organic varieties can be created. Newly formed, the Open Source Seed Initiative (OSSI: http:/ / osseeds.org) serves as a source for potential breeding material through the 
release of germplasm under the OSSI pledge, which states that varieties will remain unrestricted as well as their derivatives. Luby and Goldman [132] recently reported the release under the OSSI pledge of eight composition populations of carrot intended to be pre-breeding germplasm that represents the diversity available in current commercial varieties, paving the way for U.S. based open-source plant breeding efforts. Access to appropriate varieties best-suited to organic systems will strengthen the tools available to organic producers, potentially minimizing the yield gap with the conventional system, which would likely help promote the acceptance and transition to organic management, as well as the sustainability of the system as a whole.

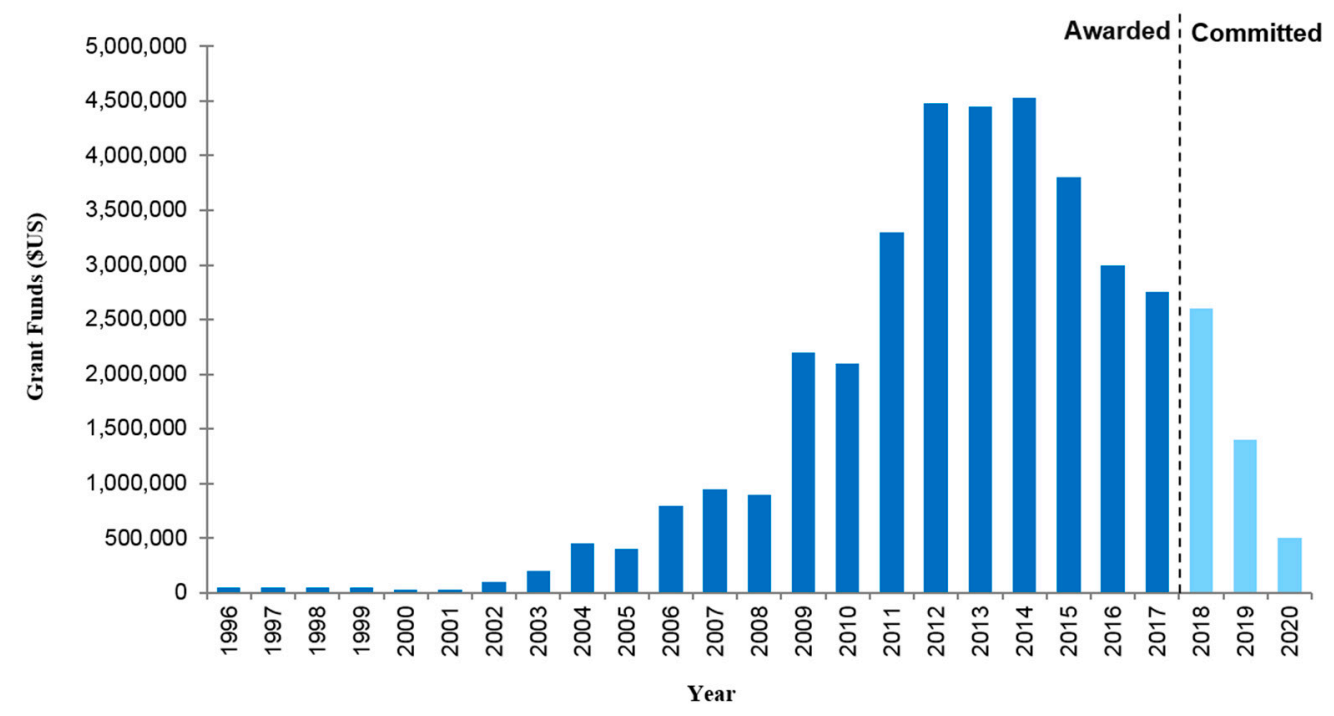

Figure 9. Funding for organic crop breeding projects in the United States. With the increasing consumer demand and expanding organic market, the development of varieties best suited for conditions inherent to organic systems becomes necessary. However, public funding for this purpose has been insufficient. Adding to data presented by the Organic Seed Alliance (OSA) State of Organic Seed 2016 report [133] illustrates how funds specifically noted for organic breeding projects have been slow to be disbursed. Although an increase in funding has been awarded and a portion committed for future research, more funding is required to develop ideal varieties that fully meet the needs of the organic system. It should be noted that funds granted after 2017 represent committed funds, it is expected that the overall funding granted in those years will ultimately be greater.

\subsection{Breeding Strategies for Organic Systems}

Since high-input production practices do not mirror those of organic systems, the varieties produced through centralized and indirect selection have not fully benefited organic producers, leaving them with a very limited number of suitable genotypes, and subsequently increasing production risks. Organic breeding programs commonly utilize classical breeding methods to create crosses of existing, often open-pollinated varieties (for allogamous species) as well as landrace or heirloom accessions with desired traits, in the hopes of reshuffling the alleles in segregating populations to enable selection of new genetic material with superior performance specifically under organic conditions. The successful development and release of wheat and corn varieties bred for production under organic management are largely due to decentralized and participatory selection methods employed. To address the heterogeneity of environmental factors and the inability to apply consistent selection pressure across diverse organic environments, breeding programs must decentralize selection [134]. Decentralized (direct) selection takes place on-site, in farmer fields, instead of solely on a research station and relying only on the evaluation and management of the staff. While decentralization by itself can be a powerful selection tool to properly fit varieties to the 
local physical production environment, valuable production and quality traits can be missed without the producer's expertise and knowledge of the crop. Comparing breeder and farmer selections of barley in Syria, Ceccarelli et al. [135] determined that there was little similarity between the two groups, a reflection of the different criteria used during selection. Additionally, the selection efficiency (defined as the ability to identify high-yielding lines by visual perception) performed by farmers in their own fields was two times greater than those of the breeders in the same fields, even though farmers are often perceived by researchers as lacking the training to make superior selections $[134,135]$. By combining the complementary skills of breeders and farmers in complex and stress environments, traits and superior genetic material can be identified and used in the development of varieties specific for organic systems. In a separate study, Ceccarelli and Grando [136] determined that decentralized and participatory breeding programs can significantly reduce the time required to release a variety. A typical breeding program, using solely classical pedigree methods requires approximately 15 years to release a variety, while participatory breeding programs reduced the time by half.

Marker-assisted selection (MAS) is a molecular tool that can be utilized in organic breeding to more quickly and precisely select genotypes. However extensive gene mapping and identification of valuable quantitative trait loci (QTL) are required, which is mostly available for major crops. Asif et al. [137] recently determined that most QTLs in wheat were developed specifically to either conventional or organic management environments and that some loci did not respond similarly under different environmental pressures. This method of selection has demonstrated great success when building pest resistance through gene pyramiding for conventional systems. A more durable, longer lasting (horizontal) resistance can be conferred using MAS than single-gene (vertical) resistance due the accumulation of several resistance genes and the reduced likelihood that a pest will be able to overcome the mechanism of resistance. Gene pyramiding through classical breeding is often difficult due to the potential for dragged undesirable phenotypic responses [74]. Although there is potential for MAS to be an efficient tool for organic breeders in the development of superior varieties, including for pest resistance, its implementation in organic breeding programs has been slow especially due to the lack of genetic information for smaller crops, as well as the associated cost and priorities of large breeding centers.

Over the past several decades, the line between traditional breeding methods and biotechnology has become increasingly blurred. The acceptance of certain breeding practices, specifically mutagenesis and cell fusion, which are currently permitted in the development of organic cultivars, have been controversial and highly debated. Mutagenesis is a breeding technique that alters the DNA using gamma radiation or chemicals, a process said to mimic the natural mutations that result from radiation, physical, and chemical stresses. Cell fusion (also called protoplast/somatic fusion) has created hybrids that exhibit optimal performance under organic conditions, most successfully for crops of the mustard family (Brassicaceae), bringing to market varieties that organic producers have come to rely on. Additionally, according to the current legal issue regarding genetic engineering in the U.S. and E.U., transgenics are strictly forbidden from organic labels. However, a more debatable issue occurs regarding the use of genetic engineering when combining genetic material from the same taxonomic family (cisgenics). This position taken by many governments opposes that of the IFOAM, which aims to set international organic standards. It defines cisgenics as genetic modification (GM) and suggests it should be banned from organic products. Presently in Europe, primarily in Germany, there is a private boycott on the use and distribution of seeds produced through cell fusion, which has recently been joined by several small organic seed companies in the E.U. and U.S. Opponents to these breeding techniques cite violations in genomic integrity due to the isolation of a gene from its natural genomic context, as well as changes in expression that result from alterations in genomic position due to random insertion [138]. Unfortunately, the discrepancies in how to address these methodologies along with the emerging biotechnology continuum will undoubtedly lead to challenges and informative discussions when assessing new breeding technologies. 


\subsection{Biotechnology and Organic Agriculture}

Indeed, the most pressing issue regarding the future of breeding for organic systems concerns the utilization of new plant breeding techniques (NPBT), which are biotechnological in nature, for the development of new varieties. The debate over the acceptance of NPBT is due to discrepancies in the definition and regulation of germplasm that is considered GM. Organic standards set forth around the world have generally been modeled based on the four principles (health, ecology, fairness, and care) as defined by IFOAM. Due to the interpretation and implication of these principles, several biotechnological breeding strategies are incompatible with organic standards. In a recent position paper, IFOAM [139] stated it considers that NPBT, including CRISPR/Cas9 genome editing, cisgenesis, genomic selection, and reverse breeding for hybrid production as "techniques of genetic modification leading to GMOs (genetically modified organisms) according to the existing E.U. legal definition", with GMOs defined as "organisms, with the exception of human beings, in which the genetic material has been altered in a way that does not occur naturally by mating and/or natural recombination". Additionally, IFOAM [139] stands firm that even though GMOs might not be in the final end-product, all GM techniques fall under GM regulation in order to maintain organic integrity and transparency. Although the present position of the E.U. on NPBT remains unclear, historically GM crops have largely not been accepted by European farmers (except in England) and the overall position on declaring a process GM has been process-based. In Australia, the current stance on GM products and labeling regulation are also process-based, following in line with the recommendation of IFOAM.

On the other hand, there are opinions that organic standards should be accepting of genomic-based selection and GM approaches, as long as the final product does not carry transgenes, such as the case of CRISPR/Cas9 genome editing or cisgene integration. Contrary to the E.U., legislation regarding GMOs in the U.S. has become increasingly product-based and requires regulation only when the genetic product differs from the non-GM counterpart. The USDA NOP strictly prohibits the use of GMOs in the production of organic crops, including the breeding techniques used to develop new varieties. Problems arise when a particular NPBT results in the development of a variety that is indistinguishable from its non-GM counterpart, however through the utilization of GMO vectors (e.g., CRISPR/Cas9 genome editing), particularly when the current legislation favors product-based GM regulation in one country while process-based in others. The issue is further complicated by questions concerning whether crop cultivars that are not considered GM and therefore do not require regulation, should be permitted for use in organic systems. Dissimilarities in the legislation, regulation, and acceptance of a product from an identical breeding technique between the leading world governments creates a host of issues concerning trade and the consistency of organic products, fostering consumer doubt and weakening the concept of organic products.

This review does not propose a position for the adoption of any particular NPBT as a non-GM breeding method, however it does seek to stress the importance in the development of a robust, science-based global standard on what constitutes a GMO. We find ourselves at a paramount time in human history, where biotechnology and the food system are becoming intertwined in ways never before imagined. By default, the organic community also finds itself at the moment where it is necessary to come to a unified global definition of GMOs and stance on GM regulation. This would not only improve the transparency of the global food system but also establish a well-defined universal organic standard able to meet consumer expectations and maintain their confidence, as well as setting a clear tone for the future. The genetics and technology of organic farming has progressed slowly compared to those of the modern conventional system, not only due to the constraints imposed by its core principles, but also due to the lesser extent of public and private funding to such programs. To remain relevant in a future driven by advancements in technology, there is a need to bring organic farming to a new technological level, however that does not mean bypassing full diligence. An extensive scientific and environmental understanding of the available NPBT should be gained before a particular process is decided upon. It is important that the organic sector begin the discussion about NPBT in order to allow the time required to properly evaluate the methodologies, potential improvements, 
or new technologies that could be developed in order to meet the needs of the organic principles. There is a likelihood that evaluating NPBT and varieties on a case-by-case basis could be necessary, or that the organic sector may also elect to accept NPBT that removes or edits genes differently than those resulting in the addition of foreign genetic material. The organic agriculture sector may choose to support genomic selection and editing-based selection in breeding programs that provide tools to maintain the core principles of organic agriculture, while leading to the development of suitable and sustainable varieties that legally remain non-GMO. While some might argue that the addition of biotechnology to the organic system would improve food security through the development varieties with increased resilience, without the proper scientific and environmental evaluation, as well as the global acceptance of NPBT, it would be irresponsible and dangerous if left unregulated, especially with the continued consolidation of international seed companies over the last few decades.

\section{Conclusions and Trends of Sustainable Organic Production}

Overall, we conclude that sustainability is a complex issue, difficult to assess by general indices. However, by dissecting individual production parameters, in the long-term, the broader adoption of organic management practices enhances system sustainability. The limited use of artificial chemicals and the reduced reliance on production methods that require high energy requirements, in both the manufacturing and implementation, highly influence the sustainability of agricultural production. Additionally, the environmental benefits, including soil building, microbial diversity and $\mathrm{C}$ sequestration provided through organic management further promotes sustainability. Despite reduced yields, the data reviewed highlight that the potential economic and nutritional benefits could outweigh this pitfall. Although sustainable use of resources can be achieved with economic benefit through the implementation of organic practices, there are still specific production parameters that can be improved in the organic management system per se. Many of the shortcomings of organic production, including $\mathrm{N}$ uptake, yield, insect and pathogen resistance, could be addressed through programs focused on breeding for organic systems.

We are currently at a unique time in human history, as we are faced with an increasing population and food demand while sources of phosphorus and non-renewable energy are predicted to decline. The development of crop varieties that exhibit optimal performance in the often-stressed organic environment would further improve the long-term efficiency and sustainability of organic production. Cultivars with the genetic capabilities to respond to the environmental conditions that are more common to organic production could potentially lead to greater global adoption and implementation of organic management practices. Additionally, system-adapted cultivars could provide food security as we navigate future hurdles due to changes in the agricultural landscape created by increasing populations, declining resources, and climate change.

Simultaneously, we are entering a new era where the food system and biotechnology are becoming heavily intertwined. With the advancements in modern breeding techniques, it is important to come to a unified global standard that defines a GM product. A well-developed standard, supported by scientific research and evidence, will help establish a global reasoning for the acceptance or prohibition of certain NPBT in the development of new varieties for organic systems. It is highly likely that the development of concise and widely accepted terms will take time. However, beginning the discussion now is important to meet the future agricultural demand. Although most of the NPBT will result in varieties that are prohibited for use in organic systems, opening the lines of communication between the biotechnological and organic sectors will allow novel breeding methods to be developed to meet the organic regulations and needs of the global organic community. To protect the integrity of organic products, as well as the environment from unforeseen consequences, it must be stressed that the decisions concerning the acceptance of NPBT must be scientifically supported and widely agreed upon.

The production of organic crops currently occurs in almost every country in the world and the consumer demand is at an all-time high, with no decline in sight. As organic production 
continues to increase, the demand for varieties suited to organic systems will also increase and organic plant breeding will become more important. It will be critical for organic agriculture to offer producers superior varieties adapted to the constraints of the production system, regardless if this occurs through traditional breeding practices or acceptable NPBT. In the event of NPBT becoming prohibited for use in organic agriculture, there will be an increased need for the development of open-pollinated and natural hybrid varieties. Overall, superior varieties are needed to bring organic agriculture to a new, more competitive position, an advantage that has benefited conventional systems for numerous years. Through the cooperation of stakeholders across the organic sector, including plant breeders, public institutions, private companies, producers and policymakers, suitable genetic resources can be made available to help ensure the continued future growth and sustainability of organic agriculture.

Acknowledgments: Open Access Author Fund (OAAF) Pilot Program from the West Virginia University Libraries paid for the publication fee of this article.

Conflicts of Interest: The authors declare no conflict of interest.

\section{References}

1. Willer, H.; Lernoud, J. The World of Organic Agriculture: Statistics and Emerging Trends 2017; FiBL-IFOAM Report; Research Institute of Organic Agriculture (FiBL), International Federation of Organic Agriculture Movements (IFOAM): Frick, Switzerland, 2017.

2. OTA-Organic Trade Association. U.S. Organic Sales Post New Record of $\$ 43.3$ Billion in 2015; Organic Trade Association: Washington, DC, USA, 2016.

3. United States Department of Agriculture-National Agricultural Statistics Service (USDA-NASS). 2012 Census of Agriculture: United States Summary and State Data. 2014. Available online: https:/ / www.agcensus.usda. gov/Publications/2012/Full_Report/Volume_1,_Chapter_1_US/usv1.pdf (accessed on 2 August 2017).

4. Reganold, J.P.; Glover, J.D.; Andrews, P.K.; Hinman, H.R. Sustainability of three apple production systems. Nature 2001, 410, 926-930. [CrossRef] [PubMed]

5. Pacini, C.; Wossink, A.; Giesen, G.; Vazzana, C.; Huirne, R. Evaluation of sustainability of organic, integrated and conventional farming systems: A farm and field scale analysis. Agric. Ecosyst. Environ. 2003, 95, 273-288. [CrossRef]

6. Henneron, L.; Bernard, L.; Hedde, M.; Pelosi, C.; Villenave, C.; Bertrand, M.; Girardin, C.; Blanchart, E. Fourteen years of evidence for positive effects of conservation agriculture and organic farming on soil life. Agron. Sustain. Dev. 2015, 35, 169-181. [CrossRef]

7. Drinkwater, L.E.; Letourneau, D.K.; Workneh, F.; van Bruggen, A.H.C.; Shennan, C. Fundamental differences between conventional and organic tomato agroecosystems in California. Ecol. Appl. 1995, 5, 1098-1112. [CrossRef]

8. Clark, M.S.; Horwath, W.R.; Shennan, C.; Scow, K.M. Changes in soil chemical properties resulting from organic and low-input farming practices. Agron. J. 1998, 90, 662-671. [CrossRef]

9. Bulluck, L.R. , III; Ristaino, J.B. Effect of synthetic and organic soil fertility amendments on Southern blight, soil microbial communities, and yield of processing tomatoes. Phytopathology 2002, 92, 181-189. [CrossRef] [PubMed]

10. Mader, P.; Fließbach, A.; Dubois, D.; Gunst, L.; Fried, P.; Niggli, U. Soil fertility and biodiversity in organic farming. Science 2002, 296, 1694-1697. [CrossRef] [PubMed]

11. Poudel, D.D.; Horwath, W.R.; Lanini, W.T.; Temple, S.R.; van Bruggen, A.H.C. Comparison of soil N availability and leaching potential, crop yields and weeds in organic, low-input and conventional farming systems in northern California. Agric. Ecosyst. Environ. 2002, 90, 125-137. [CrossRef]

12. Sileika, A.S.; Guzys, S. Drainage runoff and migration of mineral elements in organic and conventional cropping systems. Agronomie 2003, 23, 633-641. [CrossRef]

13. Bengtsson, J.; Ahnström, J.; Weibull, A.C. The effects of organic agriculture on biodiversity and abundance: A meta-analysis. J. Appl. Ecol. 2005, 42, 261-269. [CrossRef]

14. Meng, L.; Ding, W.; Cai, Z. Long-term application of organic manure and nitrogen fertilizer on $\mathrm{N}_{2} \mathrm{O}$ emissions, soil quality and crop production in a sandy loam soil. Soil Biol. Biochem. 2005, 37, 2037-2045. [CrossRef] 
15. Pimentel, D.; Hepperly, P.; Hanson, J.; Douds, D.; Seidel, R. Environmental, energetic, and economic comparisons of organic and conventional farming systems. BioScience 2005, 55, 573-582. [CrossRef]

16. Kramer, S.B.; Reganold, J.P.; Glover, J.D.; Bohannan, B.J.M.; Mooney, H.A. Reduced nitrate leaching and enhanced denitrifier activity and efficiency in organically fertilized soils. Proc. Natl. Acad. Sci. USA 2006, 103, 4522-4527. [CrossRef] [PubMed]

17. Torstensson, G.; Aronsson, H.; Bergström, L. Nutrient use efficiencies and leaching of organic and conventional cropping systems in Sweden. Agron. J. 2006, 98, 603-615. [CrossRef]

18. Tu, C.; Ristaino, J.B.; Hu, S. Soil microbial biomass and activity in organic tomato farming systems: Effects of organic inputs and straw mulching. Soil Biol. Biochem. 2006, 38, 247-255. [CrossRef]

19. Van Diepeningen, A.D.; de Vos, O.J.; Korthals, G.W.; van Bruggen, A.H.C. Effects of organic versus conventional management on chemical and biological parameters in agricultural soils. Appl. Soil Ecol. 2006, 31, 120-135. [CrossRef]

20. Yao, H.; Jiao, X.; Wu, F. Effects of continuous cucumber cropping and alternative rotations under protected cultivation on soil microbial community diversity. Plant Soil 2006, 284, 195-203. [CrossRef]

21. Fließbach, A.; Oberholzer, H.; Gunst, L.; Mäder, P. Soil organic matter and biological soil quality indicators after 21 years of organic and conventional farming. Agric. Ecosyst. Environ. 2007, 118, 273-284. [CrossRef]

22. Liu, B.; Tu, C.; Hu, S.; Gumpertz, M.; Ristaino, J.B. Effect of organic, sustainable, and conventional management strategies in grower fields on soil physical, chemical, and biological factors and the incidence of Southern Blight. Appl. Soil Ecol. 2007, 37, 202-214. [CrossRef]

23. Birkhofer, K.; Bezemer, T.M.; Bloem, J.; Bonkowski, M.; Christensen, S.; Dubois, D.; Ekelund, F.; Fließbach, A.; Gunst, L.; Hedlund, K.; et al. Long-term organic farming fosters below and aboveground biota: Implications for soil quality, biological control and productivity. Soil Biol. Biochem. 2008, 40, 2297-2308. [CrossRef]

24. Evanylo, G.; Sherony, C.; Spargo, J.; Starner, D.; Brosius, M.; Haering, K. Soil and water environmental effects of fertilizer-, manure-, and compost-based fertility practices in an organic vegetable cropping system. Agric. Ecosyst. Environ. 2008, 127, 50-58. [CrossRef]

25. Mondelaers, K.; Aertsens, J.; van Huylenbroeck, G. A meta-analysis of the differences in environmental impacts between organic and conventional farming. Br. Food J. 2009, 111, 1098-1119. [CrossRef]

26. Tuomisto, H.L.; Hodge, I.D.; Riordan, P.; Macdonald, D.W. Does organic farming reduce environmental impacts? A meta-analysis of European research. J. Environ. Manag. 2012, 112, 309-320. [CrossRef] [PubMed]

27. Hilton, S.; Bennett, A.J.; Keane, G.; Bending, G.D.; Chandler, D.; Stobart, R.; Mills, P. Impact of shortened crop rotation of oilseed rape in soil rhizosphere microbial diversity in relation to yield decline. PLoS ONE 2013, 8, e59859. [CrossRef] [PubMed]

28. McDaniel, M.D.; Tiemann, L.K.; Grandy, A.S. Does agricultural crop diversity enhance soil microbial biomass and organic matter dynamics? A meta-analysis. Ecol. Appl. 2014, 24, 560-570. [CrossRef] [PubMed]

29. Hartmann, M.; Frey, B.; Mayer, J.; Mader, P.; Widmer, F. Distinct soil microbial diversity under long-term organic and conventional farming. ISME J. 2015, 9, 1177-1194. [CrossRef] [PubMed]

30. Van Bruggen, A.H.C.; Francis, I.M.; Krag, R. The vicious cycle of lettuce corky root disease: Effects of farming system, nitrogen fertilizer, and herbicide. Plant Soil 2015, 388, 119-132. [CrossRef]

31. Agegnehu, G.; Nelson, P.N.; Bird, M.I. Crop yield, plant nutrient uptake and soil physicochemical properties under organic soil amendments and nitrogen fertilization on Nitisols. Soil Tillage Res. 2016, 160, 1-13. [CrossRef]

32. Venter, Z.S.; Jacobs, K.; Hawkins, H.J. The impact of crop rotation on soil microbial diversity: A meta-analysis. Pedobiologia 2016, 59, 215-223. [CrossRef]

33. Maharjan, M.; Sanaullah, M.; Razavi, B.S.; Kuzyakov, Y. Effect of land use and management practices on microbial biomass and enzyme activities in subtropical top- and sub-soils. Appl. Soil Ecol. 2017, 113, $22-28$. [CrossRef]

34. Tian, J.; Lou, Y.; Fang, H.; Liu, S.; Xu, M.; Blagodatskaya, E.; Kuzyakov, Y. Response of soil organic matter fractions and composition of microbial community to long-term organic and mineral fertilization. Biol. Fertil. Soils 2017, 53, 523-532. [CrossRef]

35. Bowles, T.M.; Hollander, A.D.; Steenwerth, K.; Jackson, L.E. Tightly-coupled plant-soil nitrogen cycling: Comparison of organic farms across an agricultural landscape. PLoS ONE 2015, 10, e0131888. [CrossRef] [PubMed] 
36. Sinha, E.; Michalak, A.M.; Balaji, V. Eutrophication will increase during the 21st century as a result of precipitation changes. Science 2017, 357, 405-408. [CrossRef] [PubMed]

37. Gomez-Lopez, M.D.; del Amor, F.M. Sustainable nitrogen fertilisation in sweet pepper: Assessing growth and fruit quality and the potential nitrate pollution from different organic manures. J. Sci. Food Agric. 2013, 93, 1062-1069. [CrossRef] [PubMed]

38. Atwood, D.; Paisley-Jones, C. Pesticides Industry Sales and Usage 2008-2012 Market Estimates; Environmental Protection Agency, Biological and Economic Analysis Division: Washington, DC, USA, 2017. Available online: www.epa.gov/sites/production/files/2017-01/documents/pesticides-industry-salesusage-2016_0.pdf (accessed on 5 July 2017).

39. Phelan, P.L.; Mason, J.F.; Stinner, B.R. Soil-fertility management and host preference by European corn borer, Ostrinia nubilalis (Hubner), on Zea mays L.: A comparison of organic and conventional chemical farming. Agric. Ecosyst. Environ. 1995, 56, 1-8. [CrossRef]

40. Barberi, P.; Cozzani, A.; Macchia, M.; Bonari, E. Size and composition of the weed seedbank under different management systems for continuous maize cropping. Weed Res. 1998, 38, 319-334. [CrossRef]

41. Clark, S.M.; Horwath, W.R.; Shennan, C.; Scow, K.M.; Lantni, W.T.; Ferris, H. Nitrogen, weeds and water as yield-limiting factors in conventional, low-input, and organic tomato systems. Agric. Ecosyst. Environ. 1999, 73, 257-270. [CrossRef]

42. Letourneau, D.K.; Goldstein, B. Pest damage and arthropod community structure in organic vs conventional tomato production in California. J. Appl. Ecol. 2001, 38, 557-570. [CrossRef]

43. Abbasi, P.A.; Al-Dahmani, J.; Sahin, F.; Hoitink, H.A.J.; Miller, S.A. Effect of compost amendments on disease severity and yield of tomato in conventional and organic production systems. Plant Dis. 2002, 86, 156-161. [CrossRef]

44. Baker, B.P.; Benbrook, C.M.; Groth, E., III; Benbrook, K.L. Pesticide residues in conventional, IPM-grown and organic foods: Insights from three U.S. data sets. Food Addict. Contam. 2002, 195, 427-446. [CrossRef] [PubMed]

45. Bulluck, L.R., III; Brosius, M.; Evanylo, G.K.; Ristaino, J.B. Organic and synthetic fertility amendments influence soil microbial, physical and chemical properties on organic and conventional farms. Appl. Soil Ecol. 2002, 19, 147-160. [CrossRef]

46. Moonen, A.C.; Barberi, P. Size and composition of the weed seedbank after 7 years of different cover-crop-maize management systems. Weed Res. 2004, 44, 163-177. [CrossRef]

47. Liu, B.; Gumpertz, M.L.; Hu, S.; Ristaino, J.B. Long-term effects of organic and synthetic soil fertility amendments on soil microbial communities and the development of Southern blight. Soil Biol. Biochem. 2007, 39, 2302-2316. [CrossRef]

48. Abouziera, H.F.; Hafez, O.M.; El-Metwally, I.M.; Sharma, S.D.; Singh, M. Comparison of weed suppression and mandarin fruit yield and quality obtained with organic mulches, synthetic mulches, cultivation, and glyphosate. HortScience 2008, 43, 795-799.

49. Liu, B.; Gumpertz, M.L.; Hu, S.; Ristaino, J.B. Effect of prior tillage and soil fertility amendments on dispersal of Phytophthora capsici and infection of pepper. Eur. J. Plant Pathol. 2008, 120, 272-287. [CrossRef]

50. Krauss, M.; Berner, A.; Burger, D.; Wieken, A.; Niggli, U.; Mader, P. Reduced tillage in temperate organic farming: Implications for crop management and forage production. Soil Use Manag. 2010, 26, 12-20. [CrossRef]

51. Vakali, C.; Zaller, J.G.; Kopke, U. Reduced tillage effects on soil properties and growth of cereals and associated weeds under organic farming. Soil Tillage Res. 2011, 111, 133-141. [CrossRef]

52. Baranski, M.; Srednicka-Tober, D.; Volakakis, N.; Seal, C.; Sanderson, R.; Stewart, G.B.; Benbrook, C.; Biavati, B.; Markellou, E.; Giotis, C.; et al. Higher antioxidant and lower cadmium concentrations and lower incidence of pesticide residues in organically grown crops: A systematic literature and meta-analyses. Br. J. Nutr. 2014, 112, 794-811. [CrossRef] [PubMed]

53. Birkhofer, K.; Ekroos, J.; Corlett, E.B.; Smith, H.G. Winners and losers of organic cereal farming in animal communities across Central and Northern Europe. Biol. Conserv. 2014, 175, 25-33. [CrossRef]

54. Murrell, E.G.; Cullen, E.M. Conventional and organic soil fertility management practices affect corn plant nutrition and Ostrinia nubilalis (Lepidoptera: Crambidae) larval performance. Environ. Entomol. 2014, 43, 1264-1274. [CrossRef] [PubMed] 
55. Tuck, S.L.; Winqvist, C.; Mota, F.; Ahnstrom, J.; Turnbull, L.A.; Bengtsson, J. Land-use intensity and the effects of organic farming on biodiversity: A hierarchical meta-analysis. J. Appl. Ecol. 2014, 51, 746-755. [CrossRef] [PubMed]

56. Clifton, E.H.; Jaronski, S.T.; Hodgson, E.W.; Gassmann, A.J. Abundance of soil-borne entomopathogenic fungi in organic and conventional fields in the Midwest USA with an emphasis on the effect of herbicide and fungicides on fungal persistence. PLoS ONE 2015, 10, e0133613. [CrossRef] [PubMed]

57. Feber, R.E.; Johnson, P.J.; Bell, J.R.; Chamberlain, D.E.; Firbank, L.G.; Fuller, R.J.; Manley, W.; Mathews, F.; Norton, L.R.; Townsend, M.; et al. Organic farming: Biodiversity impacts can depend on dispersal characteristics and landscape context. PLoS ONE 2015, 10, e0135921. [CrossRef] [PubMed]

58. Scheuerell, S.J.; Sullivan, D.M.; Mahaffee, W.F. Suppression of seedling damping-off caused by Pythium ultimum, P. irregulare, and Rhizoctonia solani in container media amended with a diverse range of Pacific Northwest compost sources. Phytopathology 2005, 95, 306-315. [CrossRef] [PubMed]

59. Termorshuizen, A.J.; van Rijn, E.; van der Gaag, D.J.; Alabouvette, C.; Chen, Y.; Lagerlof, J.; Malandrakis, A.A.; Paplomatas, E.J.; Ramert, B.; Ryckeboer, J.; et al. Suppressiveness of 18 composts against 7 pathosystems: Variability in pathogen response. Soil Biol. Biochem. 2006, 38, 2461-2477. [CrossRef]

60. Bonilla, N.; Vida, C.; Martinez-Alonso, M.; Landa, B.B.; Gaju, N.; Cazorla, F.M.; de Vicente, A. Organic amendments to avocado crops induce suppressiveness and influence the composition and activity of soil microbial communities. Appl. Environ. Microbiol. 2015, 81, 3405-3418. [CrossRef] [PubMed]

61. Cabras, P.; Caboni, P.; Cabras, M.; Angioni, A.; Russo, M. Rotenone residues on olives and in olive oil. J. Agric. Food Chem. 2002, 50, 2576-2580. [CrossRef] [PubMed]

62. Zhou, Y.; Wang, K.; Yan, C.; Li, W.S.; Li, H.; Zhang, N.; Zhang, Z.X. Effects of two formulations on the decline curves and residue levels of rotenone in cabbage and soil under field conditions. Ecotoxicol. Environ. Saf. 2014, 104, 23-27. [CrossRef] [PubMed]

63. Merrington, G.; Rodgers, S.L.; van Zwieten, L. The potential impact of long-term copper fungicide usage on soil microbial biomass and microbial activity in an avocado orchard. Soil Res. 2002, 40, 749-759. [CrossRef]

64. Van Zweiten, L.; Rust, J.; Kingston, T.; Merrington, G.; Morris, S. Influence of copper fungicide residues on occurrence of earthworms in avocado orchard soil. Sci. Total Environ. 2004, 329, 29-41. [CrossRef] [PubMed]

65. Wang, Q.Y.; Zhou, D.M.; Cang, L. Microbial and enzyme properties of apple orchard soil as affected by long-term application of copper fungicide. Soil Biol. Biochem. 2009, 41, 1504-1509. [CrossRef]

66. Fernandez-Calvino, D.; Soler-Rovira, P.; Polo, A.; Diaz-Ravina, M.; Arias-Estevez, M.; Plaza, C. Enzyme activities in vineyard soils long-term treated with copper-based fungicides. Soil Biol. Biochem. 2010, 42, 2119-2127. [CrossRef]

67. Fernandez-Cornejo, J.; Nehring, R.F.; Osteen, C.; Wechsler, S.; Martin, A.; Vialou, A. Pesticide Use in U.S. Agriculture: 21 Selected Crops, 1960-2008; USDA-ERS Economic Information Bulletin; United States Department of Agriculture (USDA): Washington, DC, USA, 2014. Available online: www.ers.usda.gov/ webdocs / publications / 43854/46734_eib124.pdf?v=41830 (accessed on 4 July 2017).

68. Benbrook, C.M. Trends in glyphosate herbicide use in the United States and globally. Environ. Sci. Eur. 2016, 28, 3. [CrossRef] [PubMed]

69. Grube, A.; Donaldson, D.; Kiely, T.; Wu, L. Pesticide Industry Sales and Usage: 2006 and 2007 Market Estimates; United States Environmental Protection Agency (US EPA): Washington, DC, USA, 2011.

70. Fernandez-Cornejo, J.; Wechsler, S.J. USDA Economic Research Service-Recent Trends in GE Adoption. 2016. Available online: http:/ / www.ers.usda.gov/data-products/adoption-of-genetically-engineered-crops-inthe-us/recent-trends-in-ge-adoption.aspx (accessed on 10 July 2016).

71. Allegrini, M.; Gomez, M.; Zabaloy, M.C. Repeated glyphosate exposure induces shifts in nitrifying communities and metabolism of phenylpropanoids. Soil Biol. Biochem. 2017, 105, 206-215. [CrossRef]

72. Van Hoesel, W.; Tiefenbacher, A.; Konig, N.; Dorn, V.M.; Hagenguth, J.F.; Prah, U.; Widhalm, T.; Wiklicky, V.; Koller, R.; Bonkowski, M.; et al. Single and combined effects of pesticide seed dressings and herbicide on earthworms, soil microorganisms, and litter decomposition. Front. Plant Sci. 2017, 8, 215. [CrossRef] [PubMed]

73. United States Department of Agriculture-National Agricultural Statistics Service (USDA-NASS). Organic Survey 2014. 2014. Available online: https://www.agcensus.usda.gov/Publications/2012/Online_Resources/ Organics/ORGANICS.pdf (accessed on 2 August 2017). 
74. Fess, T.L.; Kotcon, J.B.; Benedito, V.A. Crop breeding for low input agriculture: A suitable response to feed a growing world population. Sustainability 2011, 3, 1742-1772. [CrossRef]

75. Alexandratos, N.; Bruinsma, J. World Agriculture towards 2030/2050: The 2012 Revision; ESA Working Paper 12-03; Food and Agriculture Organization (FAO): Rome, Italy, 2012.

76. Hoeppner, J.W.; Entz, M.H.; McConkey, B.G.; Zentner, R.P.; Nagy, C.N. Energy use and efficiency in two Canadian organic and conventional crop production systems. Renew. Agric. Food Syst. 2006, 21, 60-67. [CrossRef]

77. Pimentel, D. Impacts of Organic Farming on the Efficiency of Energy Use in Agriculture. An Organic Center State of Science Review; The Organic Center: Washington, DC, USA, 2006; pp. 1-40.

78. Wood, R.; Lenzen, M.; Dey, C.; Lundie, S. A comparative study of some environmental impacts of conventional and organic farming in Australia. Agric. Syst. 2006, 89, 324-348. [CrossRef]

79. Pergola, M.; D’Amico, M.; Celano, G.; Palese, A.M.; Scuderi, A.; Di Vita, G.; Pappalardo, G.; Inglese, P. Sustainability evaluation of Sicily's lemon and orange production: An energy, economic and environmental analysis. J. Environ. Manag. 2013, 128, 674-682. [CrossRef] [PubMed]

80. Dal Ferro, N.; Zanin, G.; Borin, M. Crop yield and energy use in organic and conventional farming: A case study in north-east Italy. Eur. J. Agron. 2017, 86, 37-47. [CrossRef]

81. Kamali, F.P.; Meuwissen, M.P.M.; de Boer, I.J.M.; van Middelaar, C.E.; Moreira, A.; Lansink, A.G.O. Evaluation of the environmental, economic, and social performance of soybean farming systems in southern Brazil. J. Clean Prod. 2017, 142, 385-394. [CrossRef]

82. Lin, H.C.; Huber, J.A.; Gerl, G.; Hulsbergen, K.J. Effects of changing farm management and farm structure on energy balance and energy-use efficiency-A case study of organic and conventional farming systems in southern Germany. Eur. J. Agron. 2017, 82, 242-253. [CrossRef]

83. Helsel, Z.R. Using Energy and Efficiency in Pest Control, Including Pesticide Production, Use, and Management Options. 2016. Available online: http:/ / articles.extension.org/pages/62513/energy-use-and-efficiency-inpest-control-including-pesticide-production-use-and-management-options (accessed on 30 July 2017).

84. Beckman, J.; Borchers, A.; Jones, C.A. Agriculture's Supply and Demand for Energy and Energy Products. USDA-ERS Economic Information Bulletin 112. 2013. Available online: www.ers.usda.gov/webdocs/ publications /43756/37427_eib112.pdf?v=41407 (accessed on 26 July 2016).

85. Nehring, R. USDA-ERS Fertilizer Use and Markets. 2012. Available online: www.ers.usda.gov/topics/farmpractices-management/chemical-inputs/fertilizer-use-markets.aspx (accessed on 30 July 2017).

86. Ponisio, L.C.; M'Gonigle, L.K.; Mace, K.C.; Palomino, J.; de Valpine, P.; Kremen, C. Diversification practices reduce organic to conventional yield gap. Proc. R. Soc. B 2015, 282, 20141396. [CrossRef] [PubMed]

87. Clark, S.; Klonsky, K.; Livingston, P.; Temple, S. Crop-yield and economic comparisons of organic, low-input, and conventional farming systems in California's Sacramento Valley. Am. J. Altern. Agric. 1999, 14, 109-121. [CrossRef]

88. Entz, M.H.; Guilford, R.; Gulden, R. Crop yield and soil nutrient status on 14 organic farms in the eastern portion of the northern Great Plains. Can. J. Plant Sci. 2001, 81, 351-354. [CrossRef]

89. Badgley, C.; Moghtader, J.; Quintero, E.; Zakem, E.; Chappell, M.J.; Aviles-Vazquez, K.; Samulon, A.; Perfecto, I. Organic agriculture and the global food supply. Renew. Agric. Food Syst. 2007, 22, 86-108. [CrossRef]

90. Gopinath, K.A.; Saha, S.; Mina, B.L.; Pande, H.; Kundu, S.; Gupta, H.S. Influence of organic amendments on growth, yield and quality of wheat and on soil properties during transition to organic production. Nutr. Cycl. Agroecosyst. 2008, 82, 51-60. [CrossRef]

91. Cavigelli, M.A.; Hima, B.L.; Hanson, J.C.; Teasdale, J.R.; Conklin, A.E.; Lu, Y. Long-term economic performance of organic and conventional field crops in the mid-Atlantic region. Renew. Agric. Food Syst. 2009, 24, 102-119. [CrossRef]

92. Riahi, A.; Hdider, C.; Sanaa, M.; Tarchoun, N.; Kheder, M.B.; Guezal, I. Effect of conventional and organic production systems on the yield and quality of field tomato cultivars grown in Tunisia. J. Sci. Food Agric. 2009, 89, 2275-2282. [CrossRef]

93. De Ponti, T.; Rijk, B.; van Ittersum, M.K. The crop yield gap between organic and conventional agriculture. Agric. Syst. 2012, 108, 1-9. [CrossRef]

94. Seufert, V.; Ramankutty, N.; Foley, J.A. Comparing the yields of organic and conventional agriculture. Nature 2012, 485, 229-232. [CrossRef] [PubMed] 
95. Forster, D.; Andres, C.; Verma, R.; Zundel, C.; Messmer, M.M.; Mader, P. Yield and economic performance of organic and conventional cotton-based farming systems—-Results from a field trial in India. PLoS ONE 2013, 8, e81039. [CrossRef] [PubMed]

96. Lee, J.; Hwang, S.; Ha, I.; Min, B.; Hwang, H.; Lee, S. Comparison of bulb and leaf quality, and antioxidant compounds of intermediate-day onion from organic and conventional systems. Hortic. Environ. Biotechnol. 2015, 56, 427-436. [CrossRef]

97. Kniss, A.R.; Savage, S.D.; Jabbour, R. Commercial crop yields reveal strengths and weakness for organic agriculture in the United States. PLoS ONE 2016, 11, e0161673.

98. Suja, G.; Byju, G.; Jyothi, A.N.; Veena, S.S.; Sreekumar, J. Yield, quality and soil health under organic vs conventional farming in taro. Sci. Hortic. 2017, 218, 334-343. [CrossRef]

99. Bennett, M.; Franzel, S. Can organic and resource-conserving agriculture improve livelihoods? A synthesis. Int. J. Agric. Sustain. 2013, 11, 193-215. [CrossRef]

100. Sandhu, H.S.; Wratten, S.D.; Cullen, R. The role of supporting ecosystem services on conventional and organic arable farmland. Ecol. Complex. 2010, 7, 302-310. [CrossRef]

101. Cavigelli, M.A.; Teasdale, J.R.; Spargo, J.T. Increasing crop rotation diversity improves agronomic, economic, and environmental performance of organic grain cropping systems at the USDA-ARS Beltsville Farming Systems Project. Crop Manag. 2013.

102. Mohamad, R.S.; Verrastro, V.; Cardone, G.; Bteich, M.R.; Favia, M.; Moretti, M.; Roma, R. Optimization of organic and conventional olive agricultural practices from a life cycle assessment and life cycle costing perspective. J. Clean. Prod. 2014, 70, 78-89. [CrossRef]

103. Crowder, D.W.; Reganold, J.P. Financial competitiveness of organic agriculture on a global scale. Proc. Natl. Acad. Sci. USA 2015, 112, 7611-7616. [CrossRef] [PubMed]

104. Sgori, F.; Candela, M.; di Trapani, A.M.; Fodera, M.; Squatrito, R.; Testa, R.; Tudisca, S. Economic and financial comparison between organic and conventional farming in Sicilian lemon orchards. Sustainability 2015, 7, 947-961. [CrossRef]

105. Testa, R.; Fodera, M. ; Di, Trapani, A.M.; Tudisca, S.; Sgroi, F. Choice between alternative investments in agriculture: The role of organic farming to avoid the abandonment of rural areas. Ecol. Eng. 2015, 83, $227-232$. [CrossRef]

106. Bett, E.K.; Ayieko, D.M. Economic potential for conversion to organic farming: A net present value analysis in the East Mau catchment, Nakuru, Kenya. Environ. Dev. Sustain. 2016, 19, 1307-1325. [CrossRef]

107. Castro e Silva, M.; Silva, M. Leapfrogging agriculture as usual: The potential contribution and sustainability benefits of organic farming to carbon sequestration in Portugal. Int. J. Agric. Innov. Res. 2015, 4, 205-211.

108. Daugbjerg, C.; Tranter, R.; Hattam, C.; Holloway, G. Modelling the impacts of policy on entry into organic farming: Evidence from Danish-UK comparisons. Land Use Policy 2011, 28, 413-422. [CrossRef]

109. Carbonaro, M.; Mattera, M.; Nicoli, S.; Bergamo, P.; Cappelloni, M. Modulation of antioxidant compounds in organic vs conventional fruit (peach, Prunus persica L., and pear, Pyrus communis L.). J. Agric. Food Chem. 2002, 50, 5458-5462. [CrossRef] [PubMed]

110. Mitchell, A.E.; Hong, Y.; Euni, K.; Barrett, D.M.; Bryant, D.E.; Denison, R.F.; Kaffka, S. Ten-year comparison of the influence of organic and conventional crop management practices on the content of flavonoids in tomatoes. J. Agric. Food Chem. 2007, 55, 6154-6159. [CrossRef] [PubMed]

111. Dangour, A.D.; Dodhia, S.K.; Hayter, A.; Allen, E.; Lock, K.; Uauy, R. Nutritional quality of organic foods: A systematic review. Am. J. Clin. Nutr. 2009, 90, 680-685. [CrossRef] [PubMed]

112. Soltoft, M.; Nielsen, J.; Laursen, K.H.; Husted, S.; Halekoh, U.; Knuthsen, P. Effects of organic and conventional growth systems on the content of flavonoids in onions and phenolic acids in carrots and potatoes. J. Agric. Food Chem. 2010, 58, 10323-10329. [CrossRef] [PubMed]

113. Brandt, K.; Leifert, C.; Sanderson, R.; Seal, C.J. Agroecosystem management and nutritional quality of plant foods: The case of organic fruits and vegetables. CRC Crit. Rev. Plant Sci. 2011, 30, 177-197. [CrossRef]

114. Lombardo, S.; Pandino, G.; Mauromicale, G. Nutritional and sensory characteristics of "early" potato cultivars under organic and conventional cultivation systems. Food Chem. 2012, 133, 1249-1254. [CrossRef]

115. Oliveira, A.B.; Moura, C.F.H.; Gomes-Filho, E.; Marco, C.A.; Urban, L.; Miranda, M.R.A. The impact of organic farming on quality of tomatoes is associated to increased oxidative stress during fruit development. PLoS ONE 2013, 8, e56354. [CrossRef] [PubMed] 
116. Brazinskiene, V.; Asakaviciute, R.; Miezeliene, A.; Alencikiene, G.; Ivanauskas, L.; Jakstas, V.; Viskelis, P.; Razukas, A. Effect of farming system on the yield, quality parameters and sensory properties of conventionally and organically grown potato (Solanum tuberosum L.) tubers. Food Chem. 2014, 14, 903-909. [CrossRef] [PubMed]

117. Reganold, J.P.; Andrews, P.K.; Reeve, J.R.; Carpenter-Boggs, L.; Schadt, C.W.; Alldredge, J.R.; Ross, C.F.; Davies, N.M.; Zhou, J. Fruit and soil quality of organic and conventional strawberry agroecosystems. PLoS ONE 2014, 5, 12346. [CrossRef] [PubMed]

118. Vinha, A.F.; Barreira, S.V.P.; Costa, A.S.G.; Alves, R.C.; Oliveira, M.B.P.P. Organic versus conventional tomatoes: Influence on physicochemical parameters, bioactive compounds and sensorial attributes. Food Chem. Toxicol. 2014, 67, 139-144. [CrossRef] [PubMed]

119. Bach, V.; Kidmose, U.; Kristensen, H.L.; Edelenbos, M. Eating quality of carrots (Daucus carota L.) grown in one conventional and three organic cropping systems over three years. J. Agric. Food Chem. 2015, 63, 9803-9811. [CrossRef] [PubMed]

120. Cuevas, F.J.; Pradas, I.; Ruiz-Moreno, M.J.; Arroyo, F.T.; Perez-Romero, L.F.; Montenegro, J.C.; Moreno-Rojas, J.M. Effect of organic and conventional management on bio-functional quality of thirteen plum cultivars (Prunus salicina Lindl.) PLoS ONE 2015, 10, e0136596. [CrossRef] [PubMed]

121. Karlund, A.; Hanhineva, K.; Lehtonen, M.; Karjalainen, R.O.; Sandell, M. Nontargeted metabolite profiles and sensory properties of strawberry cultivars grown both organically and conventionally. J. Agric. Food Chem. 2015, 63, 1010-1019. [CrossRef] [PubMed]

122. Valverde, J.; Reilly, K.; Villacreces, S.; Gaffney, M.; Grant, J.; Brunton, N. Variation in bioactive content in broccoli (Brassica oleracea var. italica) grown under conventional and organic production systems. J. Sci. Food Agric. 2015, 95, 1163-1171. [PubMed]

123. De Pascale, S.; Maggio, A.; Orsini, F.; Barbieri, G. Cultivar, soil type, nitrogen source and irrigation regime as quality determinants of organically grown tomatoes. Sci. Hortic. 2016, 199, 88-94. [CrossRef]

124. Ren, F.; Reilly, K.; Kerry, J.P.; Gaffney, M.; Hossain, M.; Rai, D.K. Higher antioxidant activity, total flavonols, and specific quercetin glucosides in two different onion (Allium cepa L.) varieties grown under organic production: Results from a 6-year study. J. Agric. Food Chem. 2017, 65, 5122-5132. [CrossRef] [PubMed]

125. Van Bueren, E.T.L.; Jones, S.S.; Tamm, L.; Murphy, K.M.; Myers, J.R.; Leifert, C.; Messmer, M.M. The need to breed crop varieties suitable for organic farming, using wheat, tomato, and broccoli as examples: A review. NJAS-Wagening. J. Life Sci. 2011, 58, 193-205. [CrossRef]

126. Chassey, A.W.; Bui, L.; Renaud, E.N.C.; van Horn, M.; Mitchell, A.E. Three-year comparison of the content of antioxidant microconstituents and several quality characteristics in organic and conventionally managed tomatoes and bell peppers. J. Agric. Food Chem. 2006, 54, 8244-8252. [CrossRef] [PubMed]

127. Goldstein, W.A.; Schmidt, W.; Burger, H.; Messmer, M.; Pollak, L.M.; Smith, M.E.; Goodman, M.M.; Kutka, F.J.; Pratt, R.C. Maize: Breeding and field testing for organic farmers. In Organic Crop Breeding; van Bueren, E.T.L., Myers, J.R., Eds.; Wiley-Blackwell: Oxford, UK, 2012; pp. 175-189.

128. Murphy, K.M.; Hoagland, L.A.; Yan, L.; Colley, M.; Jones, S.S. Genotype x environment interactions for mineral concentration in grain of organically grown spring wheat. Agron. J. 2011, 103, 1734-1741. [CrossRef]

129. Amarante, C.V.T.D.; Steffens, C.A.; Mafra, A.L.; Albuquerque, J.A. Yield and fruit quality of apple from conventional and organic production systems. Pesqui. Agropec. Bras. 2008, 43, 333-340. [CrossRef]

130. Fernandez-Salvador, J.; Strik, B.C. Trailing blackberry genotypes differ in yield and postharvest fruit quality during establishment in an organic production system. HortScience 2015, 50, 240-246.

131. Crespo-Herrera, L.A.; Ortiz, R. Plant breeding for organic agriculture: Something new? Agric. Food Secur. 2015, 4, 25. [CrossRef]

132. Luby, C.H.; Goldman, I.L. Improving freedom to operate in carrot breeding through the development of eight open source composite populations of carrot. Sustainability 2016, 8, 479. [CrossRef]

133. Hubbard, K.; Zystro, J. State of Organic Seed, 2016; Organic Seed Alliance: Port Townsend, WA, USA, 2016. Available online: http:/ / stateoforganicseed.org (accessed on 17 November 2017).

134. Dawson, J.C.; Murphy, K.M.; Jones, S.S. Decentralized selection and participatory approaches in plant breeding for low-input systems. Euphytica 2008, 160, 143-154. [CrossRef]

135. Ceccarelli, S.; Grando, S.; Bailey, E.; Amri, A.; El-Felah, M.; Nassif, F.; Rezgui, S.; Yahyaoui, A. Farmer participation in barley breeding in Syria, Morocco and Tunisia. Euphytica 2001, 122, 521-536. [CrossRef] 
136. Ceccearelli, S.; Grando, S. Decentralized-participatory plant breeding: An example of demand driven research. Euphytica 2007, 155, 349-360. [CrossRef]

137. Asif, M.; Yang, R.C.; Navabi, A.N.; Iqbal, M.; Kamran, A.; Lara, E.P.; Randhawa, H.; Pozniak, C.; Spaner, D. Mapping QTL, selection differentials and the effect of $R h t-B 1$ under organic and conventionally managed systems in the Attila $\times$ CDC Go spring wheat mapping population. Crop Sci. 2015, 55, 1129-1142. [CrossRef]

138. Wilbois, K.P.; Baker, B.; Raaijmakers, M.; van Bueren, E.T.L. Values and principles in organic farming and consequences for breeding approaches and techniques. In Organic Crop Breeding; van Bueren, E.T.L., Myers, J.R., Eds.; Wiley-Blackwell: Oxford, UK, 2012; pp. 125-138.

139. IFOAM EU Group. New Plant Breeding Techniques: Position Paper; IFOAM EU Group: Bonn, Germany, 2015. Available online: http://www.ifoam-eu.org/sites/default/files/ifoameu_policy_npbts_position_ final_20151210.pdf (accessed on 4 October 2016).

(C) 2018 by the authors. Licensee MDPI, Basel, Switzerland. This article is an open access article distributed under the terms and conditions of the Creative Commons Attribution (CC BY) license (http:/ / creativecommons.org/licenses/by/4.0/). 